\title{
RIMSKA CESTA OD VIDA (NARONA) U DOLINI NERETVE DO SELA CICINA - HUM KOD TREBINJA
}

\author{
Željka PANDŽA \\ Filozofskifakultet \\ Odjel za arheologiju \\ Matice hrvatske b.b. \\ $\mathrm{BiH}$ - 88000 Mostar \\ E-pošta: zpandza@ymail.com

\section{Stanislav VUKOREP} \\ Društvo prijatelja starina "Hutovo" \\ $\mathrm{BIH}$ - 88394 Hutovo \\ E-pošta: svukorep@hotmail.com
}

UDK 904:625.7(497.5/.6)"652"

Izvorni znanstveni rad

Primljeno: 23. veljače 2016

Prihvaćeno: 8. lipnja 2016

\section{Sažetak}

Hodološkim i topografskim radom na terenu detaljno su utvrđene dionice ceste koja je vodila od Vida (Narona) u dolini Neretve do sela Čavaš u Popovu polju u ukupnoj dužini od oko trideset kilometara. Pokraj toga, iako ne detaljno, utvrđene su ostale dionice ceste koja ide od Čavša do Cicine kod Huma, gdje je bilo raskrižje starih putova u više pravaca. Ukupna dužina trase od Vida (Narona) iz doline Neretve do Cicine kod Huma je oko 68 kilometara. Navedena cesta nastavljala je dalje do Trebinja gdje se spajala s itinerarskom cestom (Narona - Epidaur) koja je sedamdesetih i osamdesetih godina dvadesetoga stoljeća potvrđena na terenu.

Ključne riječi: Ilirik, rimska provincija Dalmacija, Rimljani, dolina rijeke Neretve, gradnja cesta, ubikacija rimske ceste, Narona, Doljani, Čavaš u Popovu polju, Hum, dionice ceste, Epidaur. 


\section{Uvod}

Nakon konačnoga sloma Ilirika, te podjela na provincije, Rimljani su počeli graditi ceste čija je uloga bila da povežu glavni centar provincije Dalmacije Salonu s ostatkom provincije Dalmacije, ali isto tako i s provincijom Panonijom, te tako u početku grade strategijske ceste koje vremenom prerastaju u trgovačke. Neke od magistralnih cesta sagrađene su iz strategijskih razloga kao vojnički putovi a takve su bile ceste koje je izgradio namjesnik provincije Dalmacije, Publije Kornelije Dolabela. Same pripreme i izgradnja osnovnih cestovnih komunikacija u Iliriku započele su još za Augustova života, dok su u nekim oblastima izgrađene i ranije, na primjer u okolici Narone, Salone i Iadera, a možda i u Lici i oko Burnuma. Gradnja se intenzivira pogotovo u vrijeme cara Tiberija i njegova carskoga namjesnika Publija Kornelija Dolabele oko 14. do 20. godine ali je nastavljena i za vrijeme drugih careva, osobito za vladavine cara Klaudija od 41. do 54. godine. Za Dolabelino vrijeme izgrađeno je pet cesta koje su vodile iz Salone prema unutrašnjosti, a prema solinskim natpisima to su ceste: A colonia Salonitana ad fines provinciae Illyrici, viam Gabinianam ab Salonis Andetrium, a Salonis ad Hedum castellum Daesitiatium, viam ad Bathinum flumen i ad imum montem Ditionium Ulcirum per millia passuum a Salonis. Usporedo s gradnjom cesta grade se i naselja, što je jedna od važnijih zadaća Rimljana jer upravo na osnovi komunikacija i naselja koja grade uz njih, učvršćuju vlast u Iliriku nakon velikoga panonskog ustanka 9. godine. Osim toga cilj im je bio da sagrađene komunikacije omoguće što lakši kontakt, trgovinu te iskorištavanje prirodnih resursa kojima je Ilirik bogato obilovao.

\section{Izvori i proučavanje rimskih cesta}

Za proučavanje komunikacija kao i za poznavanje topografije rimske provincije Dalmacije važno je poznavati neke od izvora, npr.: Solinske natpise, ${ }^{1}$ Ptolomejevu Geografiju i tzv. itinerarie, Itinerarium Antonini, Tabulu Peutingerianu, Ravenatovu Kosmografiju, Gvidovu Geografiju, te neke od antičkih pisaca, Veleja Paterkula, Strabona, Plinija Starijeg, Ptolomeja, te Aurelija Kasiodora. ${ }^{2}$ Osim navedenih antičkih izvora koji su nužni za poznavanje topografije te utvrđivanja antičkih komunika-

1 CIL - Corpus inscriptionum Latinarum, vol. III., 1873., 3198 a + 3200; $3201+3198$ b; Ivo Bojanovski, Dolabelin sistem cesta u rimskoj provinciji Dalmaciji, Sarajevo, 1974., str. 17.

2 Esad Pašalić, Antička naselja i komunikacije u Bosni i Hercegovini, Sarajevo, 1960., str. 80; I. Bojanovski, Dolabelin sistem cesta..., str. 19-22; Petar LisičAR, "Tabula Peutingeriana i rimski itinerari", u: Materijali, 17, Beograd, 1980., str. 10-11. 
cija, na prvome mjestu su terenska istraživanja (ispitivanja) s ostatcima cesta kao i elementima koji ih prate, a to su "miljokazi, kolotečine, nasipi, ivičnjaci, kaldrme, tragovi mostova, nalazi novca, ostatci naselja i drugih građevina u zoni cesta, nekropole s nadgrobnim spomenicima i natpisima, te beneficijarski i građevinski natpisi". ${ }^{3}$ Od velike pomoći je i etnološka građa (legende i pripovijetke) vezane za stare putove kao i narodno kazivanje o pojedinim putovima, a koje je značajno jer ukazuje na starinsko podrijetlo neke ceste. To se prvenstveno odnosi na znakovite nazive kojima je stanovništvo nazivalo neki put, npr. Put Crne Kraljice, Stari drum ili Stara kaldrma, Rimski ili Grčki put (iako rjeđe) Kaurski drum ili put, Sekulan i Solarski put, te Veliki put, Stari put, Śiroki put ili Karavanski put. Osim toga istraživači se na terenu susreću i s nizom problema koji im pokatkad onemogućuju točno utvrđivanje neke rimske ceste. Da bi odredili je li neki stari put koji je i u kasnijim vremenima korišten, rimski ili nije, potrebna je velika opreznost jer bilo kakav zaključak kojega donosi mora biti utemeljen na osnovi relevantnih dokaza a to su "materijalni ostatci ceste, objekti, konfiguracija terena, osnovni pravac ceste te njegov odnos prema usputnim naseljima, te na kraju, sve provjereno epigrafskim, kartografskim i drugim podatcima". ${ }^{4}$

\section{Narona u antičko doba}

Polazište rimske ceste, koja je predmet ovoga rada, jest Narona a navedena cesta prolazila je kroz područje unutrašnjosti provincije Dalmacije (točnije kroz područje istočne Hercegovine). Navedeno područje geografski je pripadalo dijelu agera kolonije Narone (donji tok rijeke Neretve) te dijelom Epidaurskom ageru (dolina Trebišnjice). ${ }^{5} \mathrm{Da}$ je dolina Neretve od prapovijesti bila gusto naseljena potvrđuju nam gradine, tumuli kao i brojna arheološka građa, a to se ne mijenja niti za vrijeme antičkoga doba, za što su nam indikatori brojni arheološki lokaliteti na kojima se nalaze tragovi života iz toga razdoblja, te ceste koje Rimljani grade da bi što bolje povezali obalu provincije Dalmacije s unutrašnjošću. Na mjestu današnjega Vida (Narona) u dolini Neretve u 3. i 2. st. pr. Kr., postojao je lučki emporij s faktorijom grčkih trgovaca, koje vremenom postaje jedno od najznačajnijih lučkih i trgovačkih centara rimske provincije Dal-

3 I. Bojanovski, Dolabelin sistem cesta..., str. 22; Skupina Autora, Arheološki leksikon Bosne i Hercegovine, I., Zemaljski muzej Bosne i Hercegovine, Sarajevo, 1988., str. 153.

4 I. Bojanovski, Dolabelin sistem cesta..., str. 24.

5 Ivo Bojanovski, "Rimski natpisi iz doline Trebišnjice", u: Tribunia, 3, Trebinje, 1977., str. 67. 
macije. ${ }^{6} \mathrm{U}$ vremenu rimskih pohoda na Ilire Narona je postala središte velikoga peregrinskog sudskog konventa, što znači da je bila administrativno i sudsko središte šire regije. ${ }^{7}$ Pretpostavlja se da je na rang kolonije (colonia Iulia Narona) podignuta već u 1. st. pr. Kr. u doba jednoga od pripadnika Julijevske dinastije, najvjerojatnije Cezara. ${ }^{8}$

\section{Rimska cesta od Vida do Cicine i njezina važnost}

Proučavanjem rimskih cesta na području unutrašnjosti provincije Dalmacije bavili su se brojni znanstvenici. Najzaslužniji su Ballif, Patsch, Pašalić, Sergejevski, Evans, Bojanovski i dr. ${ }^{9}$ Zahvaljujući njihovu radu kroz dolinu Trebišnjice potvrđene su dvije važne komunikacije koje su ovo područje povezivale i s najudaljenijim krajevima Carstva. Prva komunikacija je išla od Akvileje preko Salone, Narone i Drača u Bizantij, te druga koja je polazila iz Epidaura te preko Trebinja vodila do Ljubomira. Navedene ceste su se spajale u Ukšićima, ${ }^{10}$ a zabilježene su u antičkim popisima putnih stanica. Prva u Antoninovu itineraru i Tabuli Peutingeriani, a druga u Tabuli Peutingeriani. ${ }^{11}$ Trasom jednoga dijela prve komunikacije bavili su se brojni znanstvenici ${ }^{12}$ ali će njezin točan smjer od Narone do Leusiniuma (Panik) osamdesetih godina dvade-

6 Branimir Gabričević, "Narona i Grci", u: Dolina rijeke Neretve od prethistorije do ranog srednjeg vijeka, Znanstveni skup - Metković, 4.-7. listopada 1977., Izdanje HAD-a, Split, 1980., str. 164; Ivo BojAnovski, Bosna i Hercegovina u antičko doba, Sarajevo, 1988., str. 117-118.

7 Nakon Oktavijanovog ilirskog rata od 35. do 33. pr. Kr. I. BojAnovski, Bosna i Hercegovina u antičko doba, str. 117.

8 NenAd CAMBi, "Antička Narona - Urbanistička topografija i kulturni profil grada", u: Dolina rijeke Neretve od prethistorije do ranog srednjeg vijeka, Znanstveni skup - Metković, 4.-7. listopada 1977., Izdanje HAD-a, Split, 1980., str. 128; I. BoJANOvsKI, Bosna i Hercegovina $u$ antičko doba, str. 117.

9 Philip BAllif - CARl PATsch, Römische strassen in Bosnien und der Herzegowina, I., Wien, 1893.; EsAd PAšAlić, Antička naselja i komunikacije u Bosni i Hercegovini, Sarajevo, 1960., str. 4-9, 103-108; Dimitrije Sergejevski, "Rimska cesta od Epidauruma do Anderbe", u: Glasnik Zemaljskog muzeja, 17, Sarajevo, 1962., str. 74-109; Arthur John Evans, Antiquarian Researches in Illyricum (parts I.II.), London, 1883.; I. Bojanovski, Dolabelin sistem cesta..., Sarajevo, 1974.

10 I. Bojanovski, "Rimski natpisi iz doline Trebišnjice", str. 67-98.

11 Ivo Bojanovski, "Novi rimski miljokazi iz Ljubomira i Poljica kod Trebinja", u: Tribunia, 1, Trebinje, 1977., str. 53.

12 Pregled pretpostavki pogledati kod: E. PAšAlić, Antička naselja i komunikacije u Bosni i Hercegovini, str. 62-64. 
setoga stoljeća utvrditi Bojanovski. ${ }^{13}$ Drugu komunikaciju od Epidaura do Trebinja prvi je opisao Evans, ali će je na terenu utvrditi Sergejevski (vodeći je dalje do Panika). ${ }^{14}$

Jedna kraća varijanta ceste od Narone do Trebinja je cesta o kojoj u ovomu radu govorimo, a vodi od Narone (današnji Vid kod Metkovića) preko Čavša do Cicine-Huma u blizini Trebinja. ${ }^{15}$ Pojedini znanstvenici su zahvaljujući pričama mještana jedan dio ove ceste "naslutili", ali do sada nije bila potvrđena na terenu. Tako je Patsch (po kazivanju mještana Kolojanja) cestu "vodio" od Doljana preko Kljenka, Petrova, Babina dola do Brštanice, gdje je "skreće" u kotlinu Hutova. ${ }^{16} \mathrm{O}$ postojanju jednoga dijela ove komunikacije govori nam i navod Obrena Đurića Kozića koji je početkom dvadesetoga stoljeća opisao stare putove kroz Popovo. ${ }^{17}$ Mještani od sela Doljana do sela Čavša cestu o kojoj pišemo i danas nazivaju Veliki put, dok dio od Čavša do Voza pod Sedlarima (ravnicom Popova polja) Siroki put, a nastavak kroz Šumu Velikim putom, odnosno Karavanskim putom. ${ }^{18}$ Sve ovo govori u prilog tomu da je navedeni put zasigurno bio prapovijesna te potom rimska cesta, u prvo vrijeme strategijskoga, a poslije i ekonomskoga karaktera. Povezivala je Naronu kao upravno

13 Godine 1962. Sergejevski je objavio preliminarno izvješće o istraživanjima rimske ceste Narona - Leusinium. Dimitrije Sergejevski, "Rimska cesta Narona - Leusinium", u: Glasnik Zemaljskog muzeja, Sarajevo, 1962., str. 711-113, ali će je arheološkim ostatcima verificirati i utvrditi tek Bojanovski. Ivo BoJANovski, "Rimska cesta Narona - Leusinium kao primjer saobraćajnog kontinuiteta", u: Godišnjak ANUBiH, Centar za balkanološka ispitivanja, 10/8, Sarajevo, 1973., str. 137-187; CIL - Corpus inscriptionum Latinarum, vol. XVII/4, 2012., str. 224-238.

14 Evans je prvi koji je opisao cestu od Cavtata do Trebinja, dok je Sergejevski istraživanja nastavio i do Panika. Dimitrije Sergejevski, "Rimska cesta od Epidauruma do Anderbe", u: Glasnik Zemaljskog muzeja, Sarajevo, 1962., str. 75-81; CIL - Corpus inscriptionum Latinarum, vol. XVII/4, 2012., str. 224-238.

15 Stanislav Vukorep (odslušao Preddiplomski sveučilišni studij, odjel Arheologija) u vremenu od 2008. do 2014. godine, hodološkim radom, "čitajući teren" utvrdio je rimsku cestu od Vida do Cicine (od 2014. do 2016. godine Željka Pandža i Stanislav Vukorep ponovno su prešli cijelu trasu).

16 CARl Patsch, Prilozi za etnologiju jugoistočne Evrope - Nekadašnja gustoća naselja ilirskoga krša. Prijevod Patscheva djela s njemačkoga uradio je dr. Ivica Šarac, a lekturu i prijevode s grčkoga, latinskoga i talijanskoga Radoslav Dodig, "Hommage: Carl Patsch (1865.-1945.)", u: Status, 8, Mostar, 2005./2006., str. 170.

17 Obren Đurić Kozić, Šuma, Površ i Zupci u Hercegovini, Beograd, 1903., str. 1150-1151. Navodi da je iz "Dubrovnika polazio karavanski put koji je vodio u unutrašnjost preko Brgata do doline Trebišnjice na Bjelin Dolu (Hum) te je odatle išao niz šumu pored sela Krnjevića i Poljica do sela Čavša pa preko Hrasnog silazio u Stolac, Mostar i dalje za Sarajevo".

18 Ove nazive smo na terenu dobili od starije populacije stanovništva. 
i trgovačko središte $s$ istočnim područjima Hercegovine (šire područje Popova, Lug, Trebinjsku šumu i Trebinje pa sve do Epidaura). Vodila je trasom preko Kolojanja, Hrasna, Popova, Huma i Trebinja do Epidaura te je to najkraća cestovna veza, zapravo najkraći strateški put između Narone i Epidaura, a za razliku od itinerarskih komunikacija nije joj primarni cilj bio povezivati važnije gradove provincije. Nakon provedenih hodoloških i topografskih istraživanja dijela trase i užega pojasa uz trasu, pretpostavljamo da je ovo bila prvenstveno vojna rimska cesta, što je bila njezina primarna uloga. Da je služila kao vojni objekt, u prilog ide i njezin relativno pravolinijski tijek, od Narone do Huma i Trebinja, u smislu najkraćega pravca, u prvom redu zbog konfiguracije terena. Arheološki ostatci ceste, tumuli, gradine, ruševna antička naselja u zoni ceste, depoi novca, nekropole, lokve, čatrnje te kazivanja autohtonoga stanovništva ${ }^{19}$ potvrđuju naše pretpostavke. Rimski traseri izbjegavali su veće usjeke i nasipe gdje je to bilo moguće te su tako trasu ceste prilagođavali reljefu terena. Dio trase išao je ravničarskim dijelom Popova polja, da bi ponovno nastavio kraškim terenom Luga i Trebinjske šume.

Uz putni pravac, koji je predmet ovoga rada, Vid - Cicina nalazi se veći broj gradina. Da su neke od njih korištene i u rimsko doba, ukazuje sitna arheološka građa (gradina u Doljanima, gradina Kolojanj na brdu Zvjezdini, Kljenak, Bokića gradina, Basarića gradina, Bukvića gradina, Čavaška gradina, Ivaniš i dr.). Osim gradina od Doljana sve do Popova, nalazimo i velik broj gomila tj. tumula koji potvrđuju važnost ovoga prometnog pravca. Od njih su posebno uočljive limitne gomile-tumuli na prijevojima uz rimsku cestu. Po svemu sudeći, ovaj putni pravac korišten je i u prapovijesno doba jer je Narona u to vrijeme bila razvijen grčki emporij u kojem se uz ostalo, trgovalo i perunikom (iris) kojom je ovo područje obilovalo. ${ }^{20} \mathrm{U}$ vrijeme pacifikacije Ilirika te konačnim

19 U arheologiji je dobro poznat fenomen da su uobičajena narodna kazivanja vezana uz ruševne ostatke iz starijih razdoblja. Priču koju ćemo navesti pripovijedala nam je Mara Šutalo rođ. 1907. godine u Grdijevićima, živi na Zaušlju, u općini Stolac. "Išao čovjek iz Metkovića goneći natovarena konja, pa kad je bio kraj Velike gomile kod Petrova dola ugleda čovjeka koji sjedi kraj puta i grije se uz vatru. Svrati k njemu, pa jami i on jedan ugljen, pa na lulu da pripali duhan. Neće. Jamij drugi, neće. Jamij treći, neće. Pa skinu lulu, te s čibukom onome čovjeku. U taj trenutak puhnu vjetar, svu žeravicu raznese, kad shvatiše da je to 'napast' bila. Onda čovjeku rekoše kada dođe doma - Otiđi bolan tu su ostali dukati, pa jamij (od tog ugljena su postali dukati)." Nedaleko od spomenute gomile pronađena je ostava rimskog novca.

20 Mladen Nikolanci, "Iris Ilyrica", u: Dolina rijeke Neretve od prethistorije do ranog srednjeg vijeka, Znanstveni skup Metković, 4.-7. listopada 1977., Izdanje HAD-a, Split, 1980., str. 155-160. 
ustrojem rimske vlasti na ovim područjima, cesta je proširena i uređena za kolski promet koji je možda korišten za izvoz drvne građe s ovoga područja. Da bi se drvo dopremilo na rijeku Neretvu, bila je potrebna uređena komunikacija čega su Rimljani itekako bili svjesni, te su stoga ovim pravcem i izgradili navedenu komunikaciju.

\section{Opis dionica pronađene rimske ceste}

Jedna od najtežih, točnije, najzahtjevnijih dionica na cijeloj trasi rimske ceste Vid (Narona) - Doljani - Čavaš - Cicina je izlaz iz Doljana na brdo Popinu i dionica koja vodi od sela Kljenak do Petrova dola (Kolojanj) ${ }^{21}$ jer je morala svladati uspon uz brdo Zvjezdinu. Polazište joj je u Naroni a već od Doljana ide brdskim dijelom do Čavša u Popovu polju, te brdsko-kraškim terenom kroz Lug i Šumu trebinjsku.

Cesta dalje ide relativno ravnim ali valovitim terenom preko Hrasna do podnožja brda Vlaka u Gornjem Hrasnu, gdje se dužim usponom penje Voznicom uz Pelinov brijeg na Čavašku gradinu ${ }^{22}$ odakle se niz brdo Zmijanje spušta u selo Čavaš u Popovu, ${ }^{23}$ gdje je režim voda u antičko doba vjerojatno bio povoljniji pa se cesta spustila u polje. Od sela Čavša trasa ceste ide prema Orašju poljskim pravcem kao Široki put do granice Luga, odakle nastavlja kao Veliki put do brda Hum kojega obilazi s istočne strane te ide do sela Cicine.

Poradi preglednosti čitavu komunikaciju od Vida do Cicine podijelili smo u osam dionica:

1. Dionica Vid - Doljani (Raičeva vala)

2. Dionica Doljani (Dubine) - Kljenak

3. Dionica Kljenak - Petrov dol

4. Dionica Petrov dol - Grbušina lokva

21 Kod Petrova dola u zaleđu Kolojanja pronađeni su ostatci temelja nekoga antičkog objekta (Crkvina) s nalazima crijepa i fragmenata keramike. S ovoga lokaliteta potječu i dvije kamene ploče; jedna rustična s motivom kola koja je prenesena u Lapidarij pred Zavičajnu kuću "Hutovo", a druga u Gornje Hrasno (nalazila se kod crkve sv. Jovana). Možda je upravo to prva putna stanica koju će pučanstvo kasnije nazivati Crkvina.

22 Na prijevoju Pelinov brijeg, gdje trasa izlazi na prijevoj između gomila (po dvije s obje strane trase), uočavaju se i temelji kružne građevine.

23 Toponim Čavaš značio bi: zavoj, čvorište, lom terena a dovodi se u vezu s romanskim riječima. 
5. Dionica Grbušina lokva - Grahovište (Gornje Hrasno)

6. Dionica Grahovište - selo Čavaš

7. Dionica Čavaš - Most pod selom Sedlari

8. Dionica Most pod Sedlarima - Cicina kod Huma

\subsection{Dionica Vid (Narona) - Doljani (Raičeva vala)}

Da je od današnjega Vida (Narona) pa preko Metkovića i Doljana prolazila rimska cesta, potvrđuju nam arheološka nalazišta na tom području, topografija te hodološki rad na terenu. Cesta je išla preko Ereševih bara u podnožju Vida prema Metkovićima, gdje su kod željezničkoga kolodvora u vinogradu Ante Gluščevića i Mihovila Omana, pronađeni ostatci zidina i mnoštvo ulomaka crijepa.

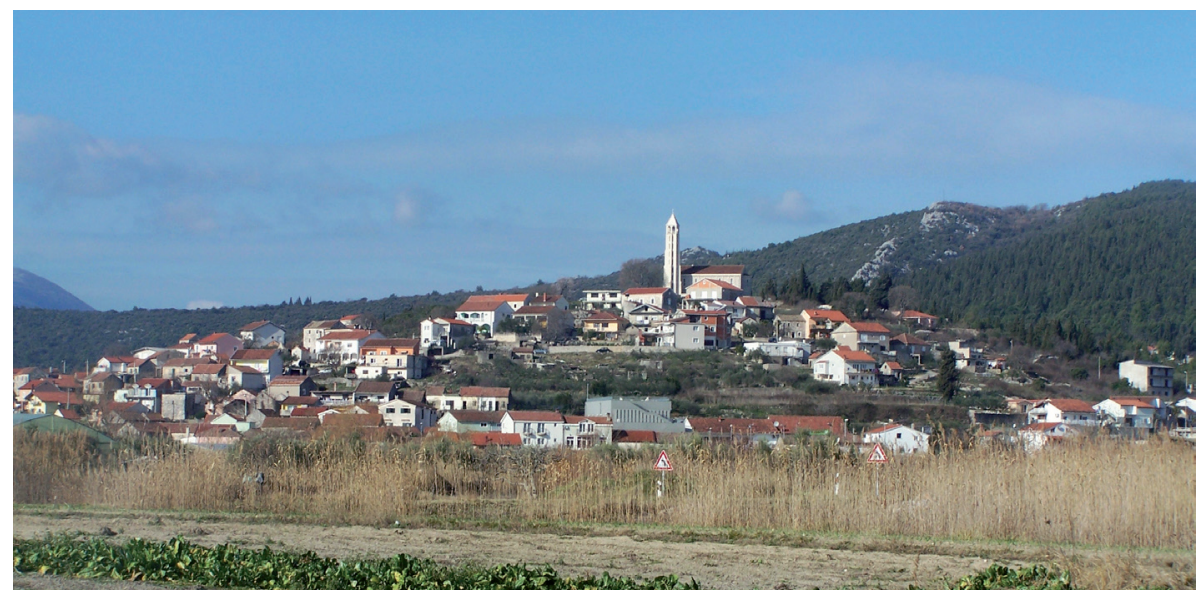

Sl. 1. Panorama Vida (foto: Ž. Pandža)

Na osnovi toga pretpostavlja se da je tu u antičko doba postojala ciglana. Također se i u susjednim vinogradima i njivama naišlo na ulomke opeke te građevnoga materijala, pa C. Patsch smatra da je tu postojalo značajnije naselje. ${ }^{24}$

Od prijelaza preko Neretve prema selu Doljani cestu je dijelom poklopio asfaltni put (do benzinske postaje Doljani). Zatim nastavlja preko doljanskoga polja kroz selo Doljani do Lazetina, odakle ide

24 Carl Patsch, Povijest i topografija Narone, Metković, 1996., str. 19. 


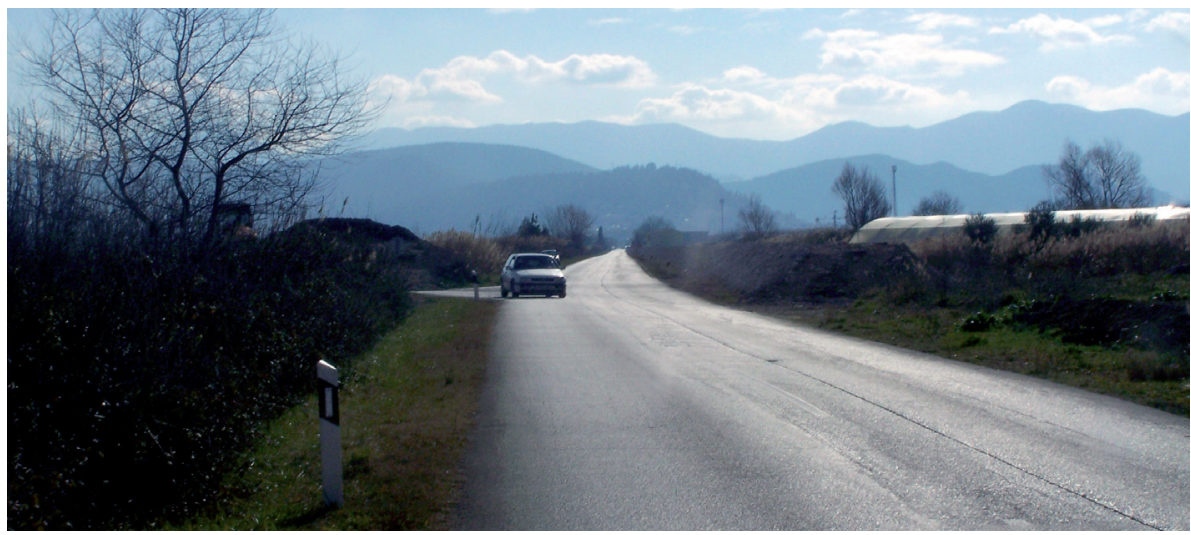

S1. 2. Cesta od Vida prema Metkoviću (foto: Ž. Pandža)

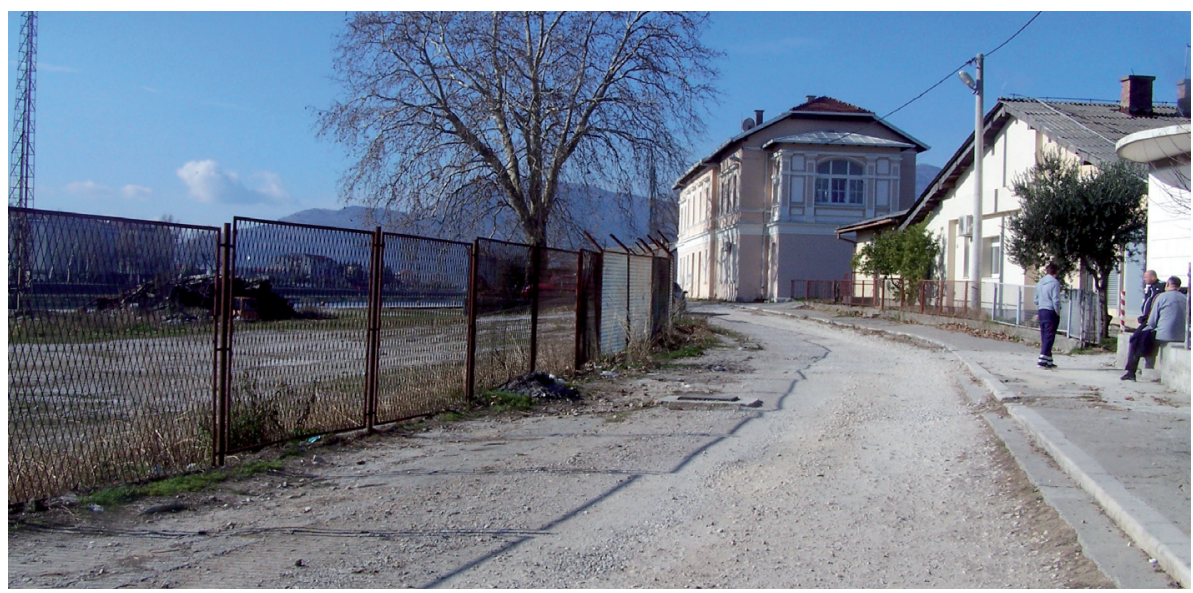

S1. 3. Mjesto na kojem se nalazila rimska ciglana (foto: Ž. Pandža)

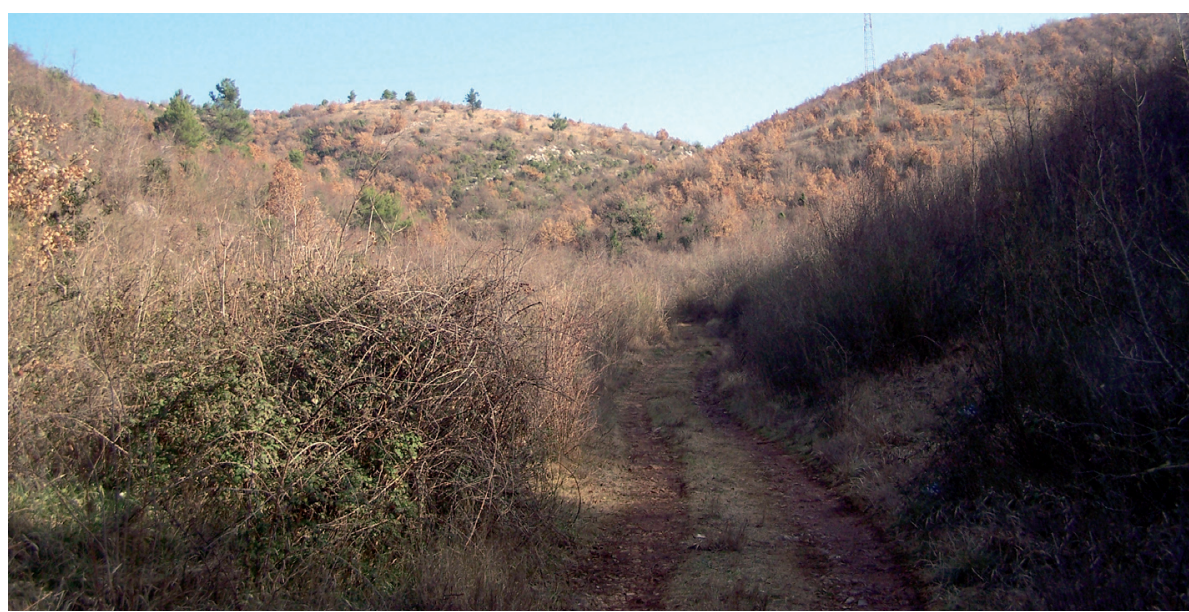

S1. 4. Udolina ispod Kljenka-Lazetine (foto: Ž. Pandža) 


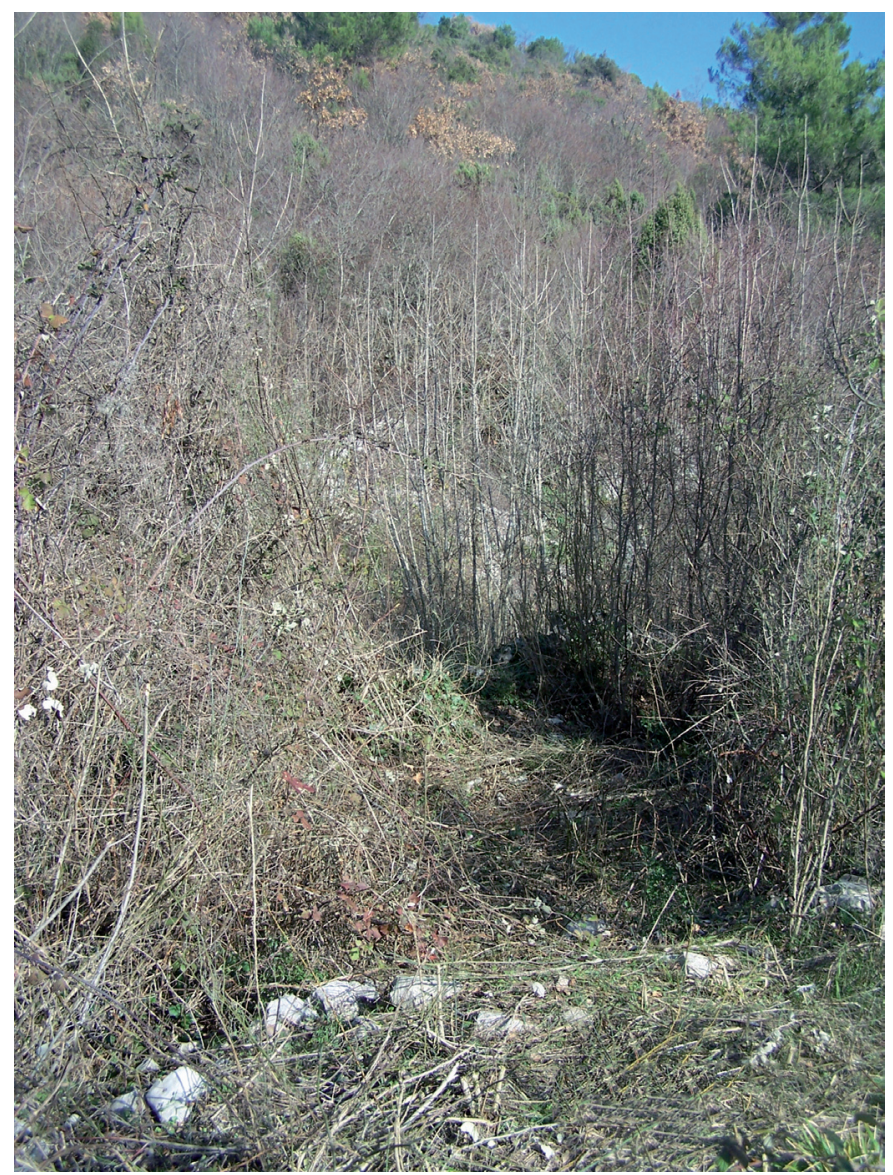

Sl. 5. Ostatci rimske ceste u širini od $4 \mathrm{~m}$ ispod brda Šibenica (foto: Ž. Pandža)

Raičevom valom prema Brstinovim ledinama, te dalje uz brdo nastavlja prema Kljenku. ${ }^{25}$

\subsection{Dionica Doljani (Dubine) - Kljenak}

Dionica Doljani ${ }^{26}$ (Dubine) - Kljenak je naše drugo pretpostavljeno polazište ove ceste zbog zanimljivoga lokaliteta Dubine u podnožju Do-

25 Mještanin Doljana Milenko Oršulić (rođ. 1953.) kazao nam je da je prije gradnje seoskoga puta prema Lazetini, postojao konjski put. Obilazeći taj dio naišli smo na cestu do pod brdo Šibenicu, obraslu raslinjem, širine $4 \mathrm{~m}$.

26 U Doljanima je registrirano rimsko naselje s ostatcima urbane arhitekture (prostorije s mozaicima) kao i građevni materijal. Osim toga pronađen je nadgrobni 
ljanske gradine ${ }^{27}$ gdje su pronađeni ulomci amfora, pitosa i drugoga arheološkog materijala. Lokalitet je zabilježen kao prapovijesno i rimsko nalazište. ${ }^{28}$ Pronađeni nalazi upućuju da se radi o antičkom skladištu, odakle se možda vršio transport roba prema unutrašnjosti, na istok. ${ }^{29}$ Također, na padinama Doljanske gradine nalazimo ostatke prapovijesne keramike, rimske keramike i opeke. ${ }^{30} \mathrm{Na}$ brdu Popina uz koji izlazi trasa rimske ceste, također je evidentirano rimsko naselje. ${ }^{31} \mathrm{Ne}$ treba zanemariti ni izlazak (u kasnijoj fazi) sa spomenute ceste Narona - Višići od Bulumovih kuća, koje su udaljene nekoliko stotina metara od lokaliteta Dubine. ${ }^{32}$

Stara cesta (kako je mještani Dračeva i danas nazivaju) ide stranom brda Popina (gdje ju je preklopila makadamska cesta građena krajem 19. stoljeća za potrebe izgradnje željezničke pruge Gabela - Dubrovnik), do pod Gomile ${ }^{33}$ na brdu Popina. Pod Gomilama trasa Stare ceste (rimske ceste), skreće desno te prolazi između Gomila ${ }^{34}$ gdje se vidi očuvana tlaka ceste, odakle skreće ulijevo, te u ravnoj liniji izlazi na visoravan kod Ristina greba.

spomenik (D. M. s. Pulcra et Ursus par(entes) Viperino filio pientissimo pos(uerunt) b(ene) m(erenti) sib(i) et suis.), CARL PATsch, "Pseudo-Skylaxovo jezero", u: Glasnik Zemaljskog muzeja, Sarajevo, 1906., str. 388; Skupina Autora, Arheološki leksikon Bosne i Hercegovine, sv. III., Zemaljski muzej Bosne i Hercegovine, Sarajevo, 1988., str. 322.

27 Parcela je po ZKI navedena kao Doljani - Dubine i Podovi - Bašta, površine $470 \mathrm{~m}^{2}$.

28 Skupina autora, Arheološki leksikon Bosne i Hercegovine, sv. III., str. 322; IvanKA MiliČEviĆ-CAPEK, "Slučajno arheološko nalazište u Doljanima kod Čapljine (preliminarno izvješće)", u: Hercegovina, 18 (10), Mostar, 2004., str. 220-221.

29 I. MiliČEvić-CAPEK, "Slučajno arheološko nalazište u Doljanima kod Čapljine (preliminarno izvješće)", str. 222.

30 Skupina autora, Arheološki leksikon Bosne i Hercegovine, sv. III., str. 322; I. MiLIČEviĆ-CAPEK, "Slučajno arheološko nalazište u Doljanima kod Čapljine (preliminarno izvješće)", str. 222.

31 Skupina Autora, Arheološki leksikon Bosne i Hercegovine, sv. III., str. 333.

32 Upravo od lokaliteta Dubine iz Doljana do Brštanice dijelom po staroj trasi izgrađena je krajem 19. st. makadamska cesta za prijevoz materijala potrebnoga za izgradnju željezničke pruge. Trasa makadamske ceste s Kljenka produžava dalje te obilaznom stranom brda Zvjezdina izlazi na Kolojanj i dalje na Brštanicu. Ispod samoga podnožja brda Zvjezdina (Orlov kuk) vidljive su dvije trase, makadamska cesta. Jedan put (konjski) ide na zaseok Brstine i dalje u Pologošu. Kaldrma turskoga puta uočava se i ispod sela Kolojanj, također ispod makadamske ceste.

33 Makadamska cesta na prijevoju kod Gomila izlazi kroz usjek te skreće lijevo i ide iznad Stare ceste i prije Ristina greba ponovno se spaja s Rimskom cestom.

34 Gomila desno od puta promjera je $24 \mathrm{~m}$. Oba tumula su oštećena, vjerojatno je kamen s njih upotrijebljen za makadamsku cestu. 


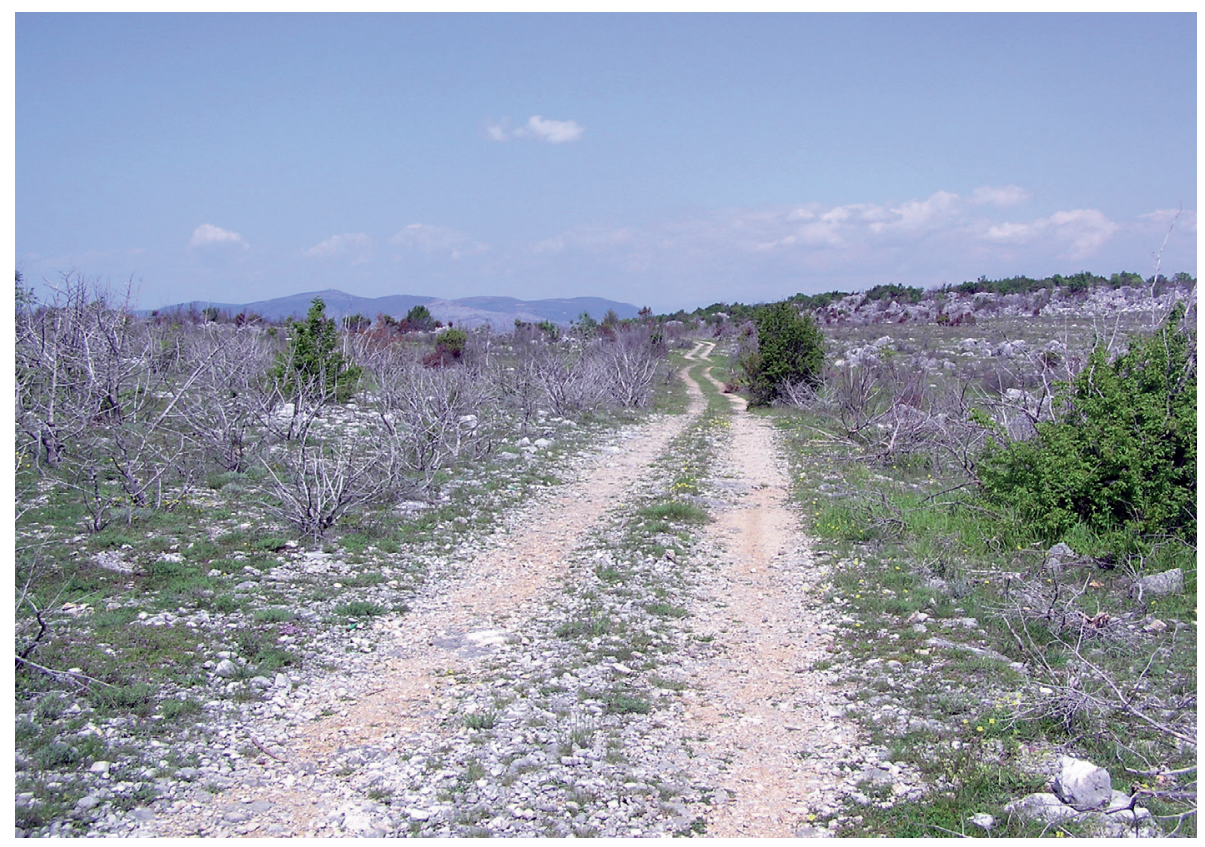

Sl. 6. Današnja cesta koja poklapa rimsku, a koja izlazi na visoravan kod Ristina greba

(foto: S. Vukorep)

Na ovoj dionici cesta je široka oko 4-5 m s podzidom i očuvanim ivičnjacima. Makadamska cesta na prijevoju kod Gomila izlazi kroz usjek te skreće ulijevo i ide iznad Stare ceste te prije Ristina greba ponovno se spaja s rimskom cestom. Pokraj Ristina greba produžava ravninom Milkove drage gdje je Staru cestu, širine oko $6 \mathrm{~m}$, prekrila makadamska cesta koja obilazi Bubrešku valu, a trasa rimske ceste pruža se u ravnoj liniji, te spušta niz uvalu (širina trase $6 \mathrm{~m}$ ). U uvali su sačuvani ivičnjaci i podzid. Vjerojatno je u kasnije doba cesta u uvalu silazila u krivini gdje se također uočavaju ivičnjaci.

Izlazeći iz uvale, cesta blago skreće desno i ponovno se spaja s makadamskom cestom, te u ravnoj liniji produžava do uvale Lakat (gdje se s lijeve strane uz samu trasu nalazi markirani tumul). Pokraj tumula cesta se spušta u uvalu Lakat, te se pokraj kraćeg dola savija uz blažu strminu, praveći duplu krivinu širine $3 \mathrm{~m}$, potom izlazi na pravac koji je ograđen starim zidinama (pučanstvo za ovako ograđen put kaže Ulica). 


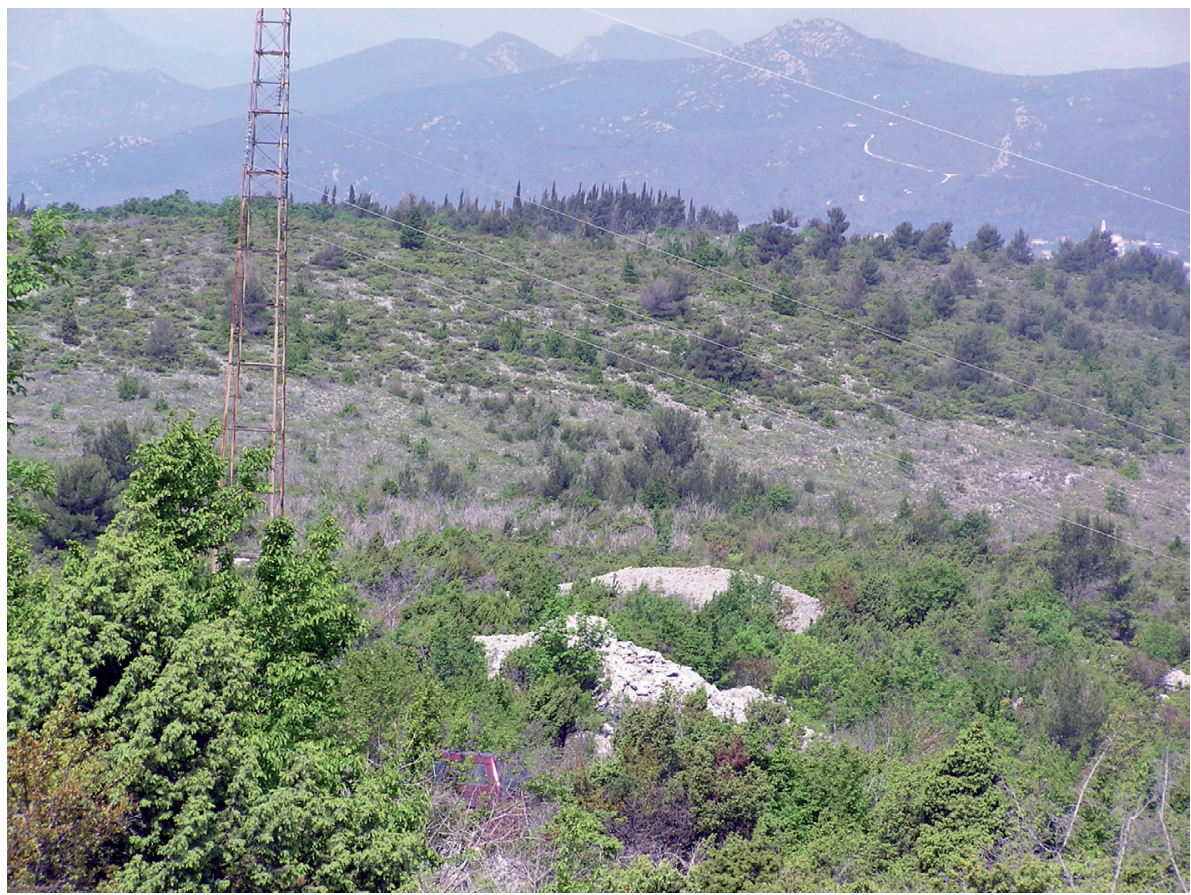

Sl. 7. Lokalitet Gomile (foto: S. Vukorep)

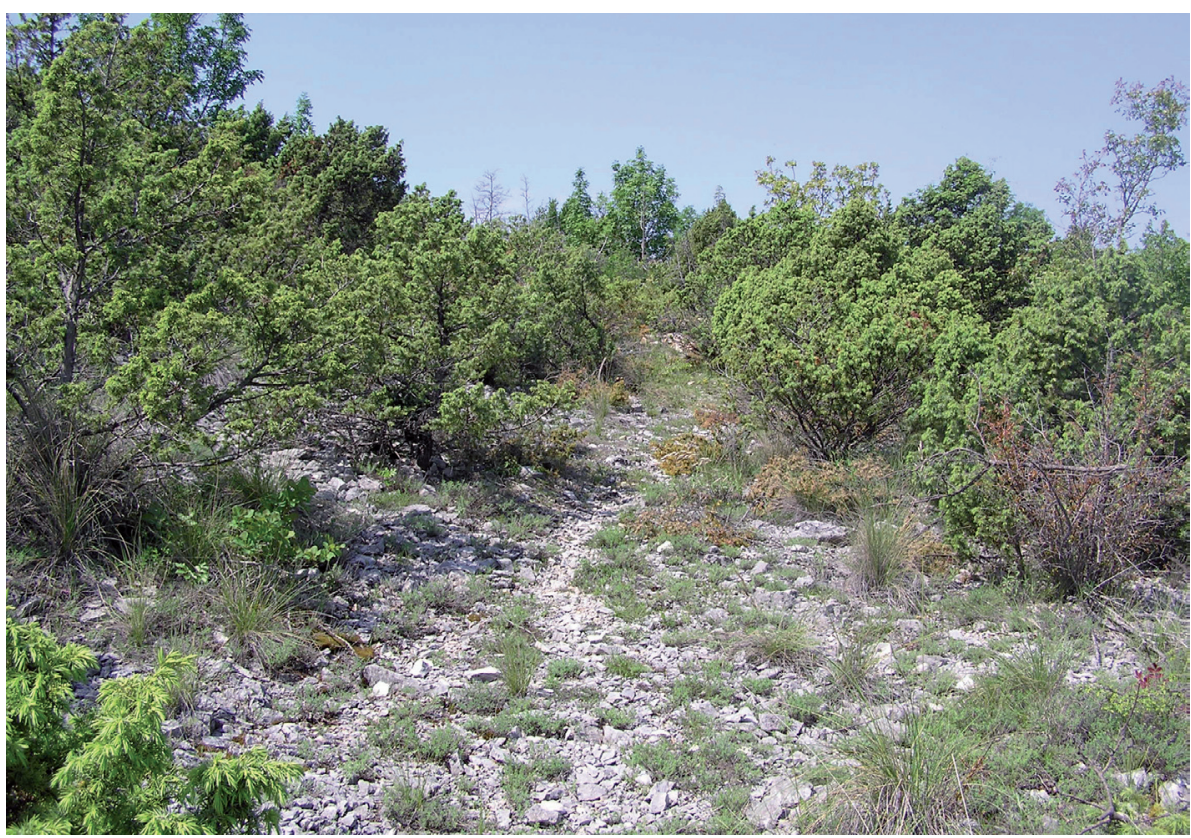

S1. 8. Dio stare ceste kod Gomila (foto: S. Vukorep) 
Makadamska cesta obilazi uvalu Lakat i spaja se sa Starom cestom na ulazu u Ulicu. Poklopljena makadamskom cestom trasa rimskoga puta nastavlja još nekoliko kilometara u smjeru naselja Kljenak. Uz ovu dionicu ceste nalazi se stara lokva, gotovo napunjena nanosima zemlje, dok je u selu Kljenak vidljivo nekoliko čatrnja.
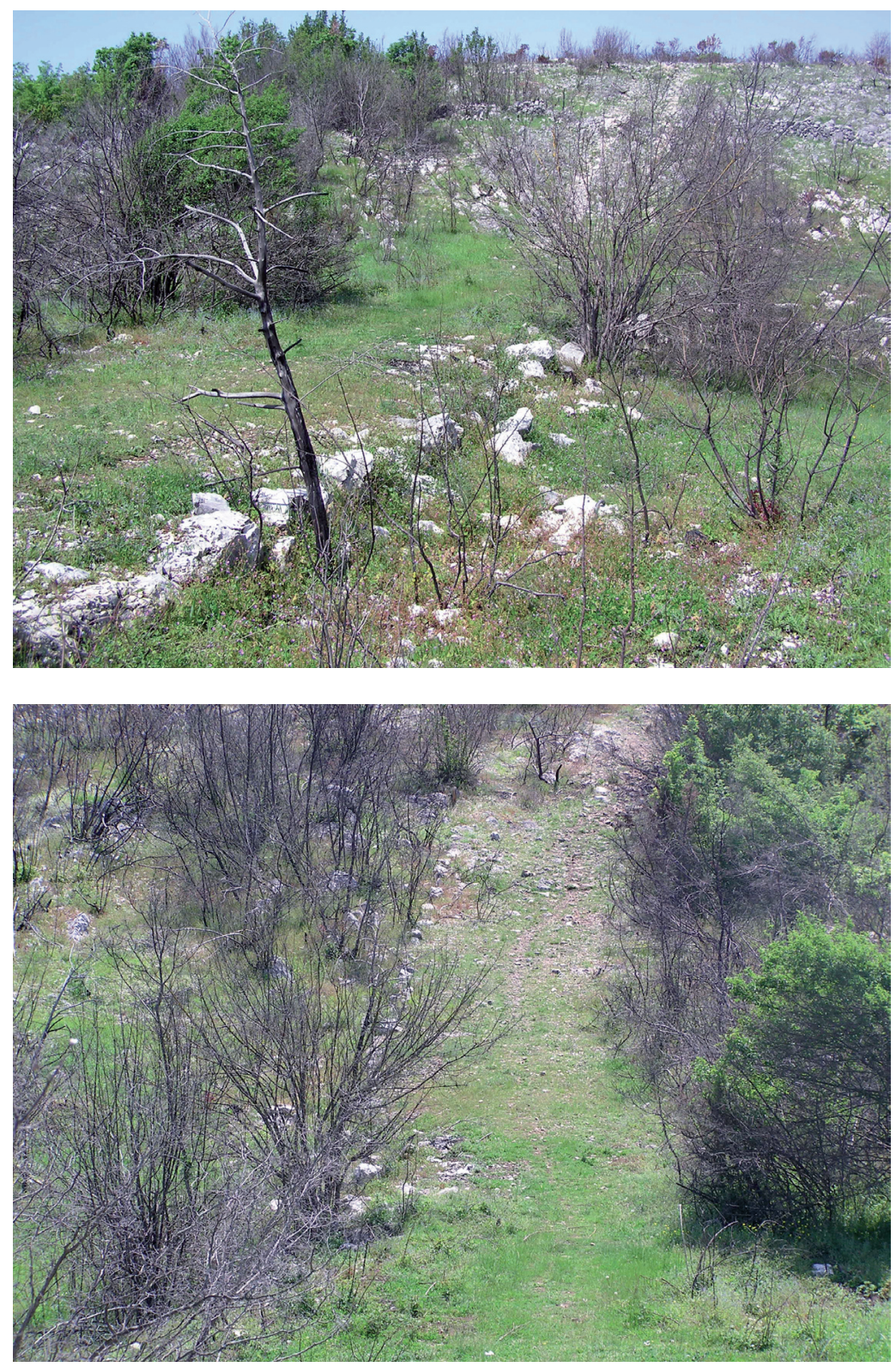

S1. 9 i 10. Ostatci rimske ceste prema Kljenku (foto: S. Vukorep) 


\section{Odvojak za Sjekose}

Od Ristina greba odvaja se konjski put niz uvalu Lakat u Sjekose. Drugi krak s rimskoga puta za Sjekose nalazi se u smjeru Pivnica te potom ide niz uvalu Lakat u Sjekose gdje je registrirano antičko nalazište. Od bivšega kolodvora u Sjekosama pruža se dobro sačuvan konjski put koji stranom brda Zvjezdina izlazi na visoravan, te na Raskrsnice kod Petrova dola.

\subsection{Dionica Kljenak - Petrov dol}

Cesta o kojoj govorimo prolazila je kroz današnje selo Kljenak te je nastavljala preko Dola kraj nekropole stećaka i hvatala se brda Zvjezdina ${ }^{35}$ (sjevernom stranom Zvjezdine što je vidljivo na karti iz 1884. godine).. ${ }^{36}$ Potom se cesta u ravnoj liniji uspinje valovitim terenom ponad uvala i nagibom što ga je mogao svladati konj koji bira najpovoljniji smjer kretanja. Pred samim izlazom na zaravan Babina dola, cesta blago skreće desno uz manji uspon, te se ponovno savija prema Bahtijevu dolu. ${ }^{37}$

$\mathrm{Na}$ navedenoj dionici, pronašli smo trasu te mjestimice očuvane ivičnjake. Cesta dalje nastavlja ravno te izlazi na Raskrsnice kod Petrova dola. Na spomenutoj karti cesta je ucrtana kao staza. Istu trasu puta od Doljana preko Kljenka do Petrova dola spominje i C. Patsch. ${ }^{38} \mathrm{Sa} \mathrm{Ra}-$ skrsnica od Petrova dola odvaja se dobro sačuvan konjski put niz valu prema Sjekosama. ${ }^{39}$

35 Put pod Zvjezdinom nosi naziv Stari put, kojim je na mazgama gonjena sol iz Gabele. Navedeni podatak ispričao nam je Ljubo Pažin, koji je Starim putom na konju gonio drva. Njegov sin Tomislav, dobar poznavalac ovoga terena, bio nam je od velike pomoći na terenu, pa im ovom prigodom zahvaljujemo. Da je cesta išla uz brdo Zvjezdinu potvrdio nam je i Franjo Menalo, koji je o toj cesti slušao od starijih mještana.

36 Karta M - 1: 6. 250 iz katastra općine Čapljina. Ovom prigodom zahvaljujemo geometru Vinki Pavlović.

37 Na cesti uza Zvjezdinu pod Bahtijevim dolom nalazi se velik broj gomila.

38 "Pričali su nam na Kolojanju da je od Doljana na Neretvi, jugoistočno od Narone, vodio jedan stari put kroz usjek Kljenak, preko predjela Glušci, do Petrova dola i Babina dola, pokraj nalazišta blaga, zatim dalje preko Opuća, Brštanice i preko dubokog procjepa Prijevora u kotlinu Hutovo." CARL PATsCh, Prilozi za etnologiju jugoistočne Evrope..., str. 170.

39 Da je iz sela Sjekosa išao Veliki put kazala nam je Kata Krešić, rođ. Ivanković (1930.), živi u Sjekosama. Posjedovna granica sela Sjekosa je do Velikoga puta koji je također i dijelom granica između općina Čapljine i Neuma. 


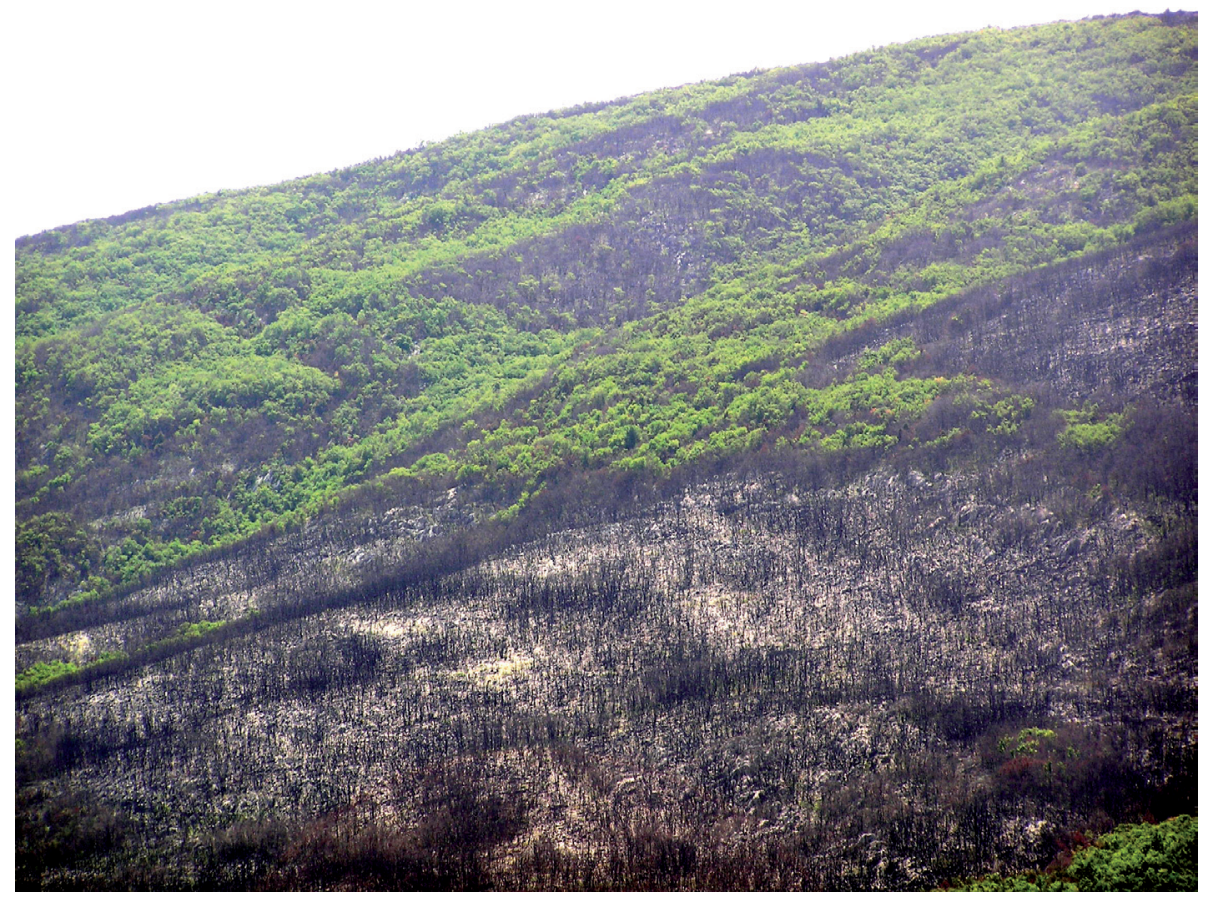

S1. 11. Sjeverni dio brda Zvjezdine (gdje je uočljiva trasa ceste koja se koso diže do Petrova dola) (foto: S. Vukorep)

\subsection{Dionica Petrov dol - Grbušina lokva}

Dužina ove dionice je $5,8 \mathrm{~km}$. Od Crkvine kod Petrova dola cesta između dva limitna tumula - gomile ${ }^{40}$ izlazi na plato Hrasna, te potom u ravnoj liniji nastavlja kraškom ravninom Babina dola gdje je vidljiv planum stare trase vješto priljubljen reljefu terena. ${ }^{41}$ Trasa je djelomično uništena izgradnjom novije ceste do podnožja Zelenikove glavice u Babinu dolu. Zbog pogodna terena vlaka ceste vjerojatno nije imala izgra-

40 Jedan od najvećih tumula nalazio se kod Grbušine lokve. U podnožju tumula otvoren je prapovijesni grob. Bitno je spomenuti također i Veliku Božićnu gomilu te Sirnu gomilu koja se nalazila uz put koji od Grbušine lokve vodi niz Mlinsko brdo u Svitavu (zanimljivo je da i C. Patsch pretpostavlja da ocrtavaju liniju nekog starog puta). Osim ovih registrirao je gomilu na predjelu Miškova brda. Potrebno je spomenuti i gomilu-tumul uza samu cestu na prijevoju, odakle ide priključni put prema kući Vlahe Njavre u Međuljuće.

41 Ruža Jurković Zekić (1924.) rođena na Babinu dolu, kazala je da su stariji ljudi pričali da je niz Hrasno preko Babina dola za Metković išao Stari (Veliki) put. 

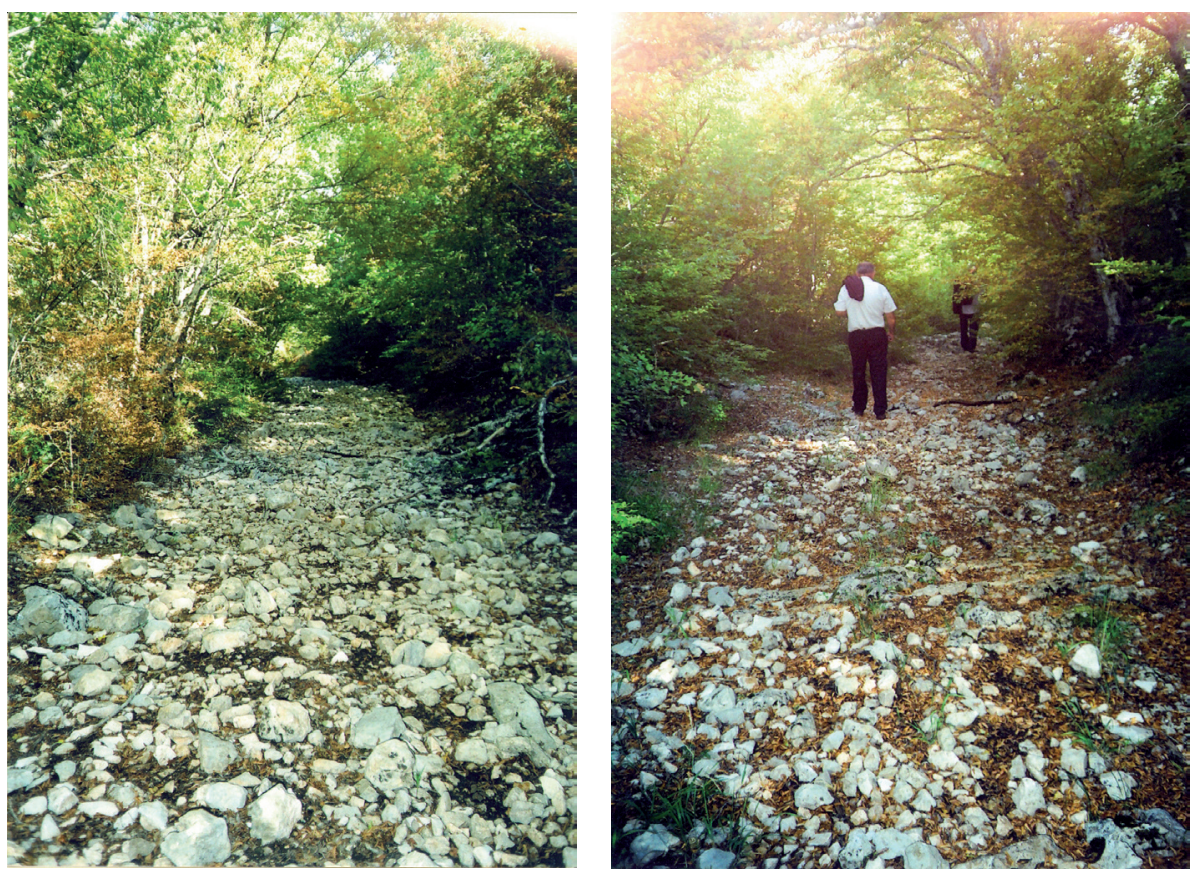

Sl. 12 i 13. Ostatci ceste preko Babina dola (foto: S. Vukorep)

đen nasip niti usjek. Da je navedena cesta išla ovim pravcem, potvrđuje rimski novac pronađen na Babinom dolu nedaleko od same dionice. ${ }^{42}$

Na jednom dijelu dionice preko Babina dola odvajao se krak ceste Opućem, potom je kroz Cerov klanac iznad sela Brštanice, te niz Rogove i Mramor vodio prema Hutovu, gdje se spajao s komunikacijom Ston - Stolac.

42 Na parceli Vidoja Jurkovića u Babinu dolu pastiri su poslije kiše nalazili bakreni novac. Na istomu mjestu u rujnu 1899. godine pronađena je ostava s novcem koja se sastojala isključivo od sestercija. Na mjestu pronalaska nisu pronađeni ostatci građevine niti naselja. Najmlađi poznati novčić datira u vrijeme Komoda (Cohen, 508, br. 30. iz godine 186.). Zemaljski muzej iz Sarajeva otkupio je 32 novčića, dok je preostali dio privatno rasprodan. C. РAтsCH, Prilozi za etnologiju jugoistočne Evrope..., str. 170. 


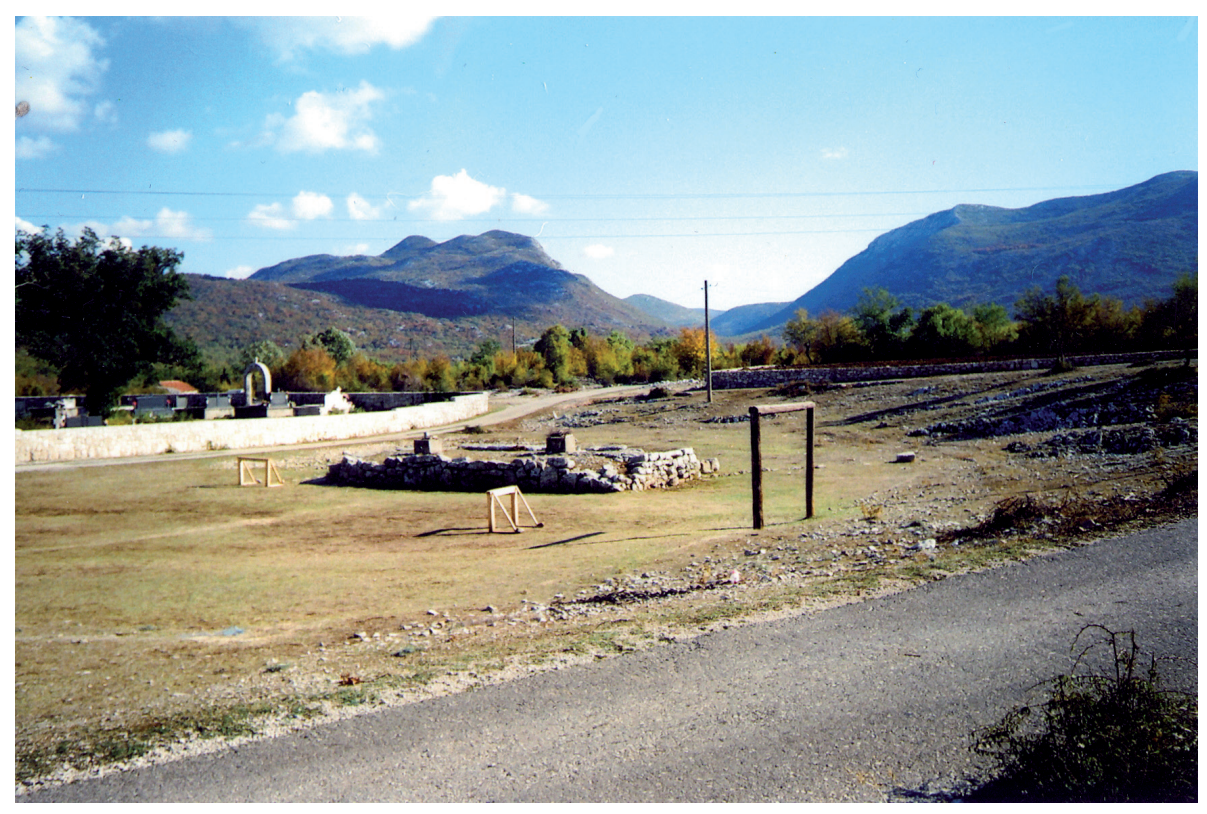

S1. 14. Stara cisterna (čatrnja) na Brštanici. Desno od čatrnje uza zid groblja nalaze se ostatci rimske građevine (foto: $\mathrm{S}$. Vukorep)

Patsch je ovaj pravac označio kao dionicu ceste Tilurium - Scodra preko Hutova $^{43}$ a koji je doveden u pitanje pronalaskom miljokaza cara Tita $\mathrm{u}$ Prudu. ${ }^{44} \mathrm{Na}$ ovaj putni pravac u selu Mramoru izlazi put koji ide iz sela Brštanice (od crkve sv. Ante). Uza samu dionicu, na lokalitetu Špadnji greb - Bekanova dubrava nalazi se manja nekropola stećaka. ${ }^{45}$

Preko Koštrenice niz Kobilju prodo u blagom padu dionica se spušta na Zidak odakle se odvaja za selo Brštanicu. ${ }^{46}$ Iako zarasla u vegetaciju,

43 Isto.

Napomena: Patschu nisu ukazali na nastavak dionice uz Hrasno i Popovo, pa ga je to ponukalo da skrene cestu prema Hutovu. Što ne znači da nije i preko Hutova išla cesta, ali za Slano. U ovoj studiji C. Patsch nije uklopio područje Gornjega Hrasna pa tako nije ni vidio nastavak ceste za Popovo ovim pravcem.

44 Carl Patsch, Manja istraživanja u Naroni i oko nje, Metković, 1997., str. 28; I. BojANOvsKI, "Rimska cesta Narona - Leusinium kao primjer saobraćajnog kontinuiteta", str. 137.

45 Odavde se odvaja pješačka staza prema i ispod Baraka, prelazi željezničku prugu i produžava na Kozaricu.

46 Nekoliko stotina metara od Barake kuda prolazi trasa, te iznad željezničke stanice Hrasno prema Hutovu, nalazilo se rimsko naselje Kućine, preko kojega je prešla trasa željezničke pruge te uništila naselje. "Prigodom gradnje pruge, temelji zidi- 
cesta je uočljiva, pruža se te spušta na zaravan i ide prema Baraci (željeznički stambeni objekt), gdje je na Rampi presijeca bivša trasa željezničke pruge. Potom cesta nastavlja prema zaseoku Kozarici, gdje je prati nekoliko tumula.

Od željezničke pruge (Rampe) dionica ceste obrasla je vegetacijom (prema izjavi mještana bila je široka oko $4 \mathrm{~m}$ ), ide desno vlakom, pa iznad Šutalovih kuća, Mejdana na Kozarici, Maslaćevinom ograđen starim zidinama između Sirnog i Općenog dola ${ }^{47}$ izlazi na sadašnju trasu asfaltnoga puta i istom trasom ide do Grbušine lokve. ${ }^{48}$

\section{Šutalov put za Dašnicu}

Pokraj Velike gomile (uništene izgradnjom suvremene komunikacije) na platou Grbušine lokve odvajali su se putovi za Svitavu niz Mlinsko brdo, Šutalov put preko Isjeka ${ }^{49}$ koji je izlazio na Dašnicu, te dalje nastavljao za Stolac.

\subsection{Dionica Grbušina lokva - Grahovište (Gornje Hrasno)}

Put od Grbušine lokve do Grahovišta (crkva sv. Nikole) u Gornjem Hrasnu mještani nazivaju Veliki put. Na Cerovici (Maslaći) nekoliko stotina metara jugoistočno od trase, pronađen je brončani novčić Konstantina II. ${ }^{50}$ Od Grbušine lokve cesta se blago penje (ispod gradina) prema Obaljenom groblju. Također, i ovu dionicu mještani nazivaju Veliki put, a ograđen je starim zidovima dolaskom austrougarske uprave. ${ }^{51}$ Dionica rimske ceste presijecala je groblje na kome se nalazi nekropola stećaka. Potom je u ravnoj liniji nastavljala preko Vlake, te vodila iznad asfaltne ceste do prijevoja kod skretanja prema kući Vlahe Njavre u Međuljuću.

na tu su poslužili kao kamenolom." C. PATsCh, Prilozi za etnologiju jugoistočne Evrope..., str. 174. Uz istočni zid katoličkoga groblja na Brštanici nalaze se temelji manjeg antičkog objekta (koji je neregistriran).

47 Vlasništvo obitelji Maslać.

48 Kod Grbušine lokve bio je Veliki tumul - gomila, jedan od najvećih na ovomu prostoru.

$49 \mathrm{Na}$ brdu Isjek postoji gomila i vidikovac s kojega se vidi Narona (Vid) i more. Dio brda Isjeka od gomile prema Svitavi nosi naziv Osoje, a sunčana strana Mosor obrastao je u drvo zeleniku.

50 C. РAтsch, Prilozi za etnologiju jugoistočne Evrope..., str. 174.

51 Janja Raguž-Rogonjić (1876.-1966., rođena u Podkuli, Gornje Hrasno) pamtila je vrijeme kada nigdje nije bilo međe - zida u Hrasnu, nego tek nešto na Kolojanju i u Papčevoj vinogradini u Gornjem Hrasnu. Ni Veliki put u tom razdoblju nije bio ograđen. 
Ovaj dio stare trase zarastao je $\mathrm{u}$ vegetaciju a današnju cestu prati $\mathrm{u}$ razmaku oko pedeset metara. Nedaleko od groblja s desne strane ceste nalazio se tumul koji je devastiran i raznesen, kao i dio trase preko Vlake (prilikom izgradnje asfaltne ceste). Drugi tumul, zarastao u vegetaciju, također s desne strane ceste, nalazi se oko stotinjak metara dalje u Njavrinoj ogradi. ${ }^{52} \mathrm{Na}$ ovaj dio rimske ceste od Obaljenoga groblja do
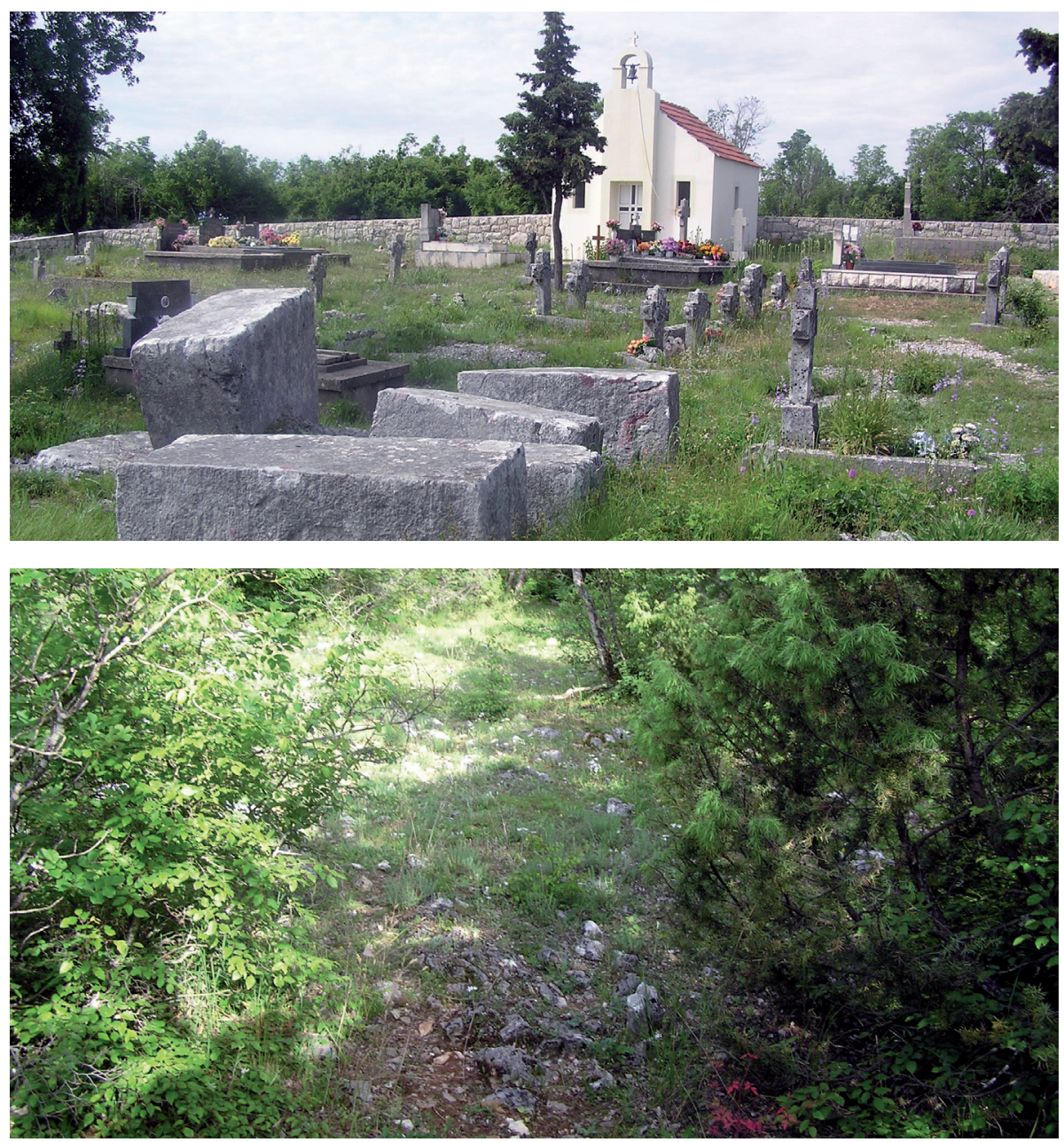

Sl. 15 i 16. Obaljeno groblje i ostatak Velikoga puta kroz Njavrine ograde ispod Osječenice (foto: $\mathrm{S}$. Vukorep)

52 Na devastiranom tumulu, uočavaju se vrata - ulaz, kao da je bila zidana građevina ili zidana grobnica. Nalazi se na oko pedeset metara od asfaltne ceste u Njavrinoj ogradi prema Osječenici. 
skretanja za Osječenicu (kojeg nije preklopila makadamska cesta) ukazao nam je jedan od mještana. ${ }^{53}$

Cestu presijeca skretanje za Osječenicu a ograđena je zidovima. Nasuprot skretanju na Osječenicu nalazi se Raičeva lokva (ili Kaočina). ${ }^{54}$ Trasu ceste od raskrižja u Međuljuću do Toplice mještani zovu Donji put, Veliki put ili cesta. Na dionici Međuljuće - Raskrsnica - Toplice, u blizini Hrasna nađene su spurile. ${ }^{55}$

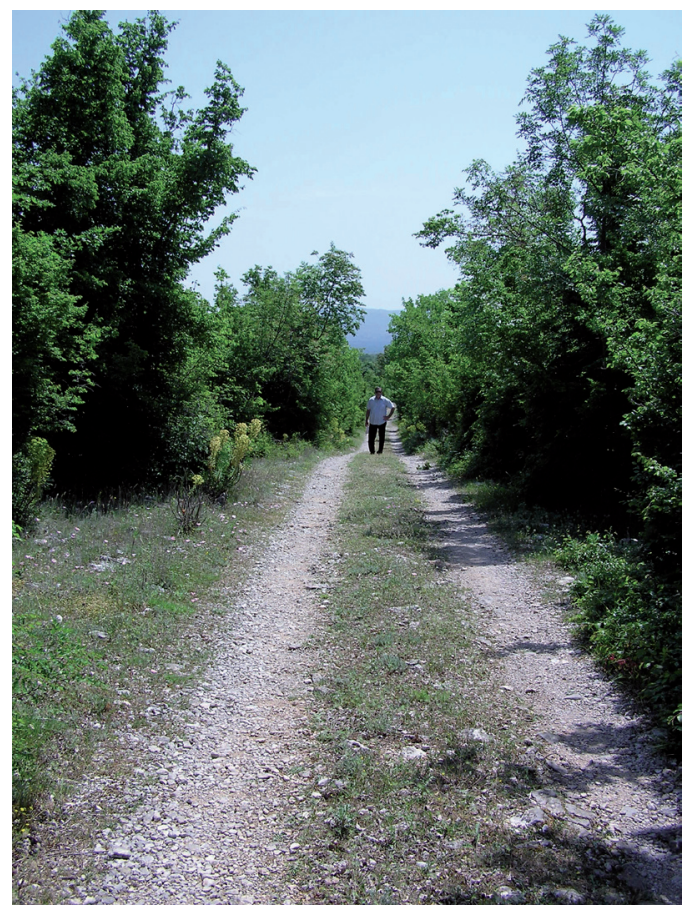

Sl. 17. Dio trase Velikoga puta od skretanja Međuljuće prema Toplici (foto: Ž. Pandža)

53 Branko Njavro iz Osječnice (1948.) kojemu je otac Marijan (1910.?) pričao i pokazao staru trasu kroz njihovu ogradu. Također mu je baka Cvija (rođ. 188? u Podkuli, Gornje Hrasno, udala se 1907. na Osječenicu, Donje Hrasno) pričala da je ispod Osječenice išla stara cesta od Popova prema Brštanici i Metkoviću, te da su tim putem išli karavani.

54 Na najvišoj koti ove dionice iznad Međuljuća (kod skretanja prema kući Vlahe Njavre) bio je tumul koji je uništen u Domovinskome ratu. Mještanin (Vide Vidika Raguž-Čolić) kazao nam je da je "Austrija 1903./1904. godine od Međuljuća prema Toplici i Gornjem Hrasnu po nekom Starom putu izgradila makadamsku cestu".

55 Podatak nam je dao Ivan Krešić Radin rođen 1936. godine, koji se prisjeća čudnih usjeka na toj cesti (po opisu radi se vjerojatno o spurilama). 
$\mathrm{Na}$ ovoj dionici mjestimice su sačuvani ivičnjaci koji nisu uzidani u stari zid kojim je ograđena cesta do Toplice. ${ }^{56}$ Gradina Meteriz nalazi se s lijeve strane u zoni ceste u Krešića brdu. Iznad Krešića kuća u Međuljuću, asfaltni put skreće lijevo te kroz Vinine i Crnoglav izlazi na Stolove i dalje za Stolac. Sa Stolova se odvaja također asfaltni put prema selu Rabrani i kod Stare čatrnje izlazi na trasu rimske ceste.

Rimska cesta (Veliki put) prolazila je kroz nekropolu i staro groblje na Toplici koje se u novije vrijeme proširilo preko trase, pa se cesta ovdje kratko gubi, da bi potom iza groblja nastavila ispod gradine Stražnica i nekoliko tumula kroz Obradovića razdolje. ${ }^{57} \mathrm{U}$ blizini čatrnje na Tucakovića razdolju ispod sela Rabrane ${ }^{58}$ (stotinjak metara desno od postojećega asfaltnog puta), stara trasa ceste zarasla je u vegetaciju ${ }^{59}$ i dijelom je uništena obradivim površinama. S toga mjesta u ravnoj liniji vodi kroz Dubravu i ograde Klačine.

U Klačinama, nedaleko od stare trase, nalazi se nekoliko tumula kao i lokva Donja Brestica te njive Lupežnice. Sadašnja trasa ceste krivuda, a trasa Velikoga puta išla je u smjeru Grahovišta.

\section{Križanje na Toplici}

Na Toplici se nalazi križanje s pravcem Glumina - Svitava. Ovaj put vodio je kroz Dašnicu i niz uvalu Sin do silazio u Svitavu. Na prijevoju uza stari konjski put, koji vodi od zaseoka Međuljuće prema Dašnici, nalazi se gomila Poluđelica (koja je nekada bila obzidana kamenim

$56 \mathrm{Na}$ Toplici se nalazi nekropola stećaka kao i prastara lokva Toplice. Suženje ceste pred Toplicom nastalo je kada je austrijski nasip "izlokala voda" (Austrija je 1903./1904. po nekom starom putu izgradila makadamsku cestu).

57 Pred samim Razdoljem uz cestu nalaze se tri tumula u nizu. Na trećem je pronađeno ulomaka keramike. Tumul je prezidan na slovo T ogradnim zidovima. Također, s lijeve strane ceste nalazi se još jedan tumul. U blizini ceste nalazi se i stara lokva Trnovac.

58 Gomila kod Stare čatrnje pod selom Rabrani obilježavala je križanje putova kao i Zborna gomila na Grahovištu.

59 Uočili smo na karti isprekidane crte od Tucakovića razdolja do Papčeve vinogradine, pa smo pretpostavili da je to ostatak trase rimskoga puta, koga je neki austrijski geometar ucrtao po kazivanju nekog starijeg mještanina. Potražili smo nekoga od sadašnjih stanovnika Potkule tko bi nam mogao to potvrditi. Kada smo pitali Vidu Vidiku Raguža-Čolića za staru trasu, nije mu bilo poznato, ali kada smo napomenuli trasu kroz Grabovine, rekao nam je sljedeće: "Ima nešto za što sam se stalno pitao što je, je li to mogao biti neki stari put." 


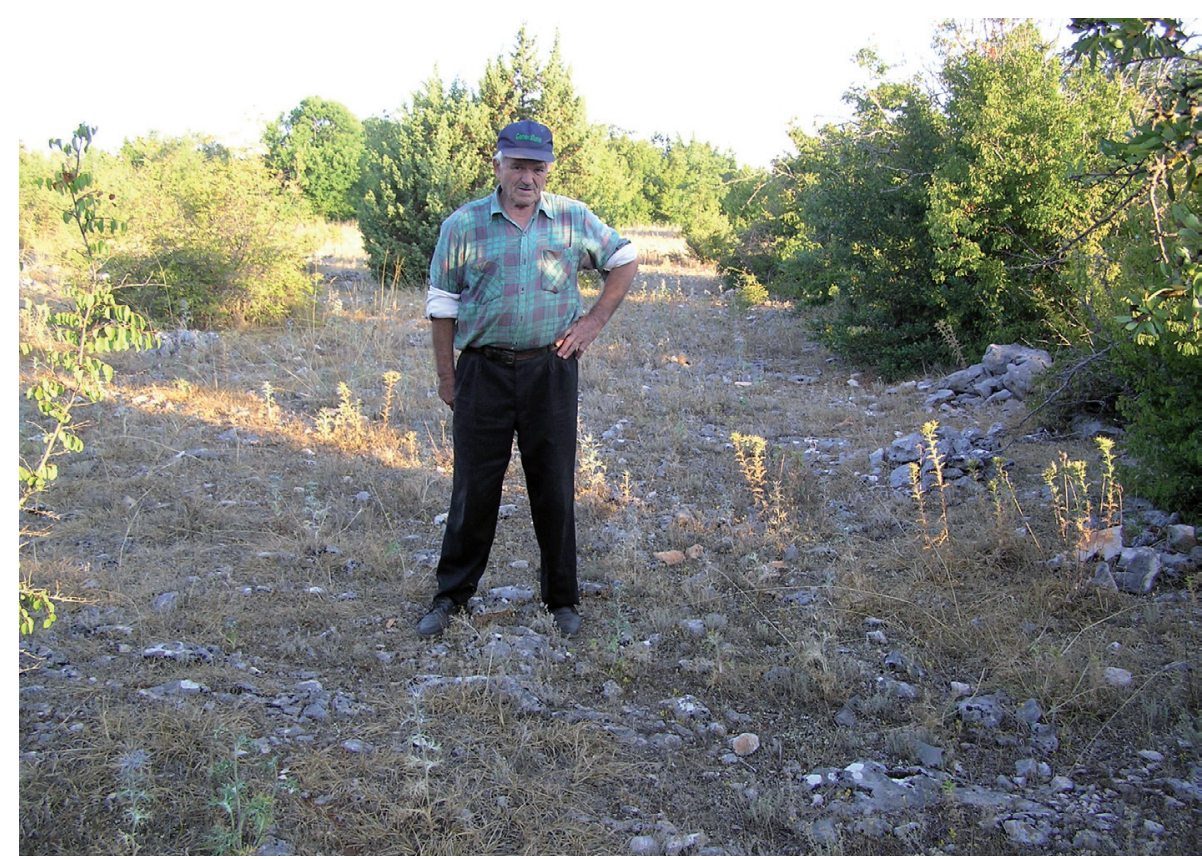

S1. 18. Ostatci ceste od Tucakovića razdolja do Papčeve vinogradine (foto: S. Vukorep)

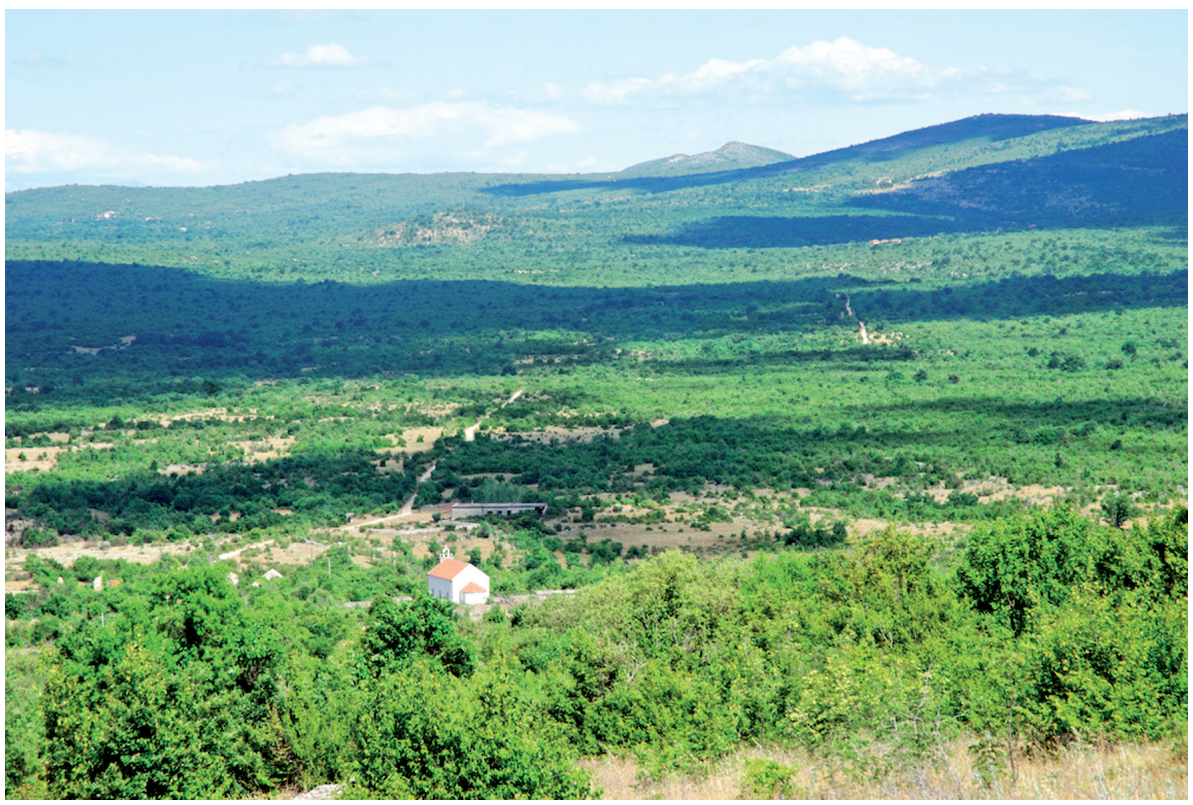

S1. 19. Panorama Hrasna s putnim pravcem prema Grahovištu (foto: S. Vukorep) 
prstenovima). ${ }^{60}$ Jedan krak ceste (to jest, konjski put) s Toplice za Gluminu ide ravnim terenom Grabovina pokraj dviju gomila i preko prijevoja Prisjeka gdje se nalazi gomila, te vodi u selo Gluminu i dalje preko Popova ili Okladnice - Hutovo, prema Slanome i Stonu. Od stare čatrnje na Bjelinovu brijegu preko Prkačinove Dubrave na Siječja gdje se odvaja put za Previš i konjski put iz Glumine, skreće prema Vučjim kamenicama i crkvi u Donjem Hrasnu.

Od Razdolja ispod sela Rabrani, trasa nastavlja dalje kroz Grabovine, a zidanjem ograde izbačena je izvan nje, pa je sadašnji asfaltni put treća trasa kroz Gornje Hrasno do Grahovišta. Na Grahovištu siječe put od Konjskog (Popova) za Stolac, a drugi iz Glumine koji Podgradinjem skreće lijevo prema Zbornoj gomili. Prolaz pokraj gomile siječe asfaltnu cestu te pokraj Staroga groblja koje je zaraslo u draču i grabovinu, spaja se prije Gaja s putom koji vodi iz Popova, uz Konjsko pa preko Kozarice i Udore za Stolac.

Jugoistočno od trase na prostoru od sela Vlake prema Pobrđu nalaze se tri gradine, Žarkovića, Bukvića i Knežića gradina. Najdominantnija je Knežića gradina s koje se mogla nadgledati cesta i raskrižje na Grahovištu, kao i uspon uz Voznik i Vlaku. ${ }^{61}$

\section{Križanje Grahovište (Elezovići)}

U Grahovištu se odvaja krak ceste koji ide pokraj lokve u Vinogradinama (od lokve se odvaja jedan put za Podgradinje i Pobrđe) i čatrnje Balinuše, te preko prijevoja Meteriz. Potom nastavlja nešto niže od Pijevića gradine i niz Konjsko, gdje se ispod sadašnje asfaltne ceste nadzire trasa staroga puta. Trasa je bila omeđena ivičnjacima koji su i danas donekle

60 Parcela Brdo na kojoj se nalazi tumul vlasništvo je Nikole (Nišole) Krešića Adamova. Tumul Poluđelica nalazi se na Brdu prema Dašnici, to jest, na samom prijevoju brda, nedaleko od staroga puta koji je vodio iz Međuljuća pokraj Krešića (Špičića) kuća za Dašnicu i dalje prema Stocu. Visine je oko 2,5 m i promjera 24 m. Prema konstrukciji koja je jedinstvena na ovomu području ali i po veličini, vjerojatno je bio "Kneževski grob". Postavljenim položajem vjerojatno je grobni tumul vladara s Bokića gradine koja se izdiže nekoliko stotina metara sjevernije. Bio je obzidan kamenim prstenovima koji su nažalost dignuti a kamen je ugrađen u suhozidni dvostruki zid kojim je ograđen posjed. Dio konstrukcije prstenova i sada se uočava na tumulu. Po sjevernom obodu tumula ozidan je spomenuti kameni zid koji sa sjeverne strane uokviruje tumul.

61 Na vrhu gradine te na padinama, pronalazilo se ulomaka keramike. Prve generacije učenika (krajem 19. st. iz škole u Gornjem Hrasnu), pričali su da ih je učitelj vodio na ovu gradinu da mu skupljaju arheološke nalaze: keramiku, kamene kugle, a nalazili su i metalnih predmeta. 
vidljivi. Od Konjskoga cesta se spušta u Popovo polje, odnosno preko polja u Velju Među ili prema Morašnici, odakle preko Trebimlje (kod Ravna u Popovu polju) ${ }^{62}$ vodi za Slano.

Drugi pravac ide preko Kozarice za Stolac, a od zaselka Gaj odvaja se konjski put preko Rujeva dola za Čavaš, te za Bančiće i dalje za Ljubinje. Ispod Grahovišta (negdje kod Doma) nalazi se zanimljiv lokalitet Banovina, na kome rimsku cestu presijeca konjski put iz Glumine ${ }^{63}$ koji u Medanovini izlazi na trasu konjskog puta Popovo - Stolac.

\subsection{Dionica Grahovište - selo Čavaš}

Iz sela Grahovišta cesta ide uz uspon Voznik, ${ }^{64}$ te pokraj zaseoka Mahala (Elezovina) izlazi na zaravan do manje uvale. Kasnija trasa kroz uvalu pravi obilaznicu prilagođenu konjskim karavanima. Iz uvale, uz kraći strmi uspon izlazi na brdo Vlaku, ispod Orlova kuka.

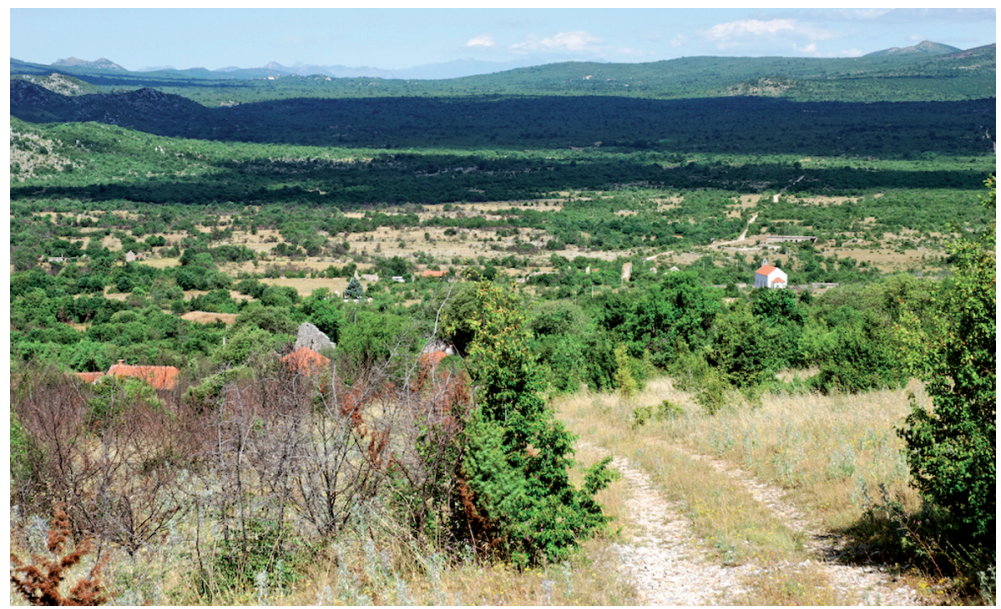

S1. 20. Trasa ceste uz Voznik (foto: S. Vukorep)

62 I. Bojanovski, "Rimski natpisi iz doline Trebišnjice", str. 82-86. Na ovom lokalitetu 1925. godine pronađen je nadgrobni spomenik u obliku stele koji se datira u 2. st. Na istom mjestu (parcela M. Kriste) pronađeni su ostatci rimskoga naselja (zidovi, zidana grobnica kojoj je već spomenuta stela služila kao poklopac, rimski građevni materijal i dr.) Vrijednost ovoga spomenika je što se na njemu prvi put spominje municipij Diluntum (kojega autor smješta u Stolac) koji je bio upravni centar kojem je pripadala i Trebimlja. Na spomeniku se spominje dekurion municipija Diluntuma P. Aplije Plaso koji je pripadao staležu domaće gradske elite a koji je u Trebimlji imao imanje.

63 Na izlazu iz sela Glumine, prema Herovinama, zanimljiv je toponim Zidak (ukazuju na postojanje zida što je asocijativno za grad).

64 Pod ovim imenom mještani poznaju dijelove ceste u planinskim područjima. 


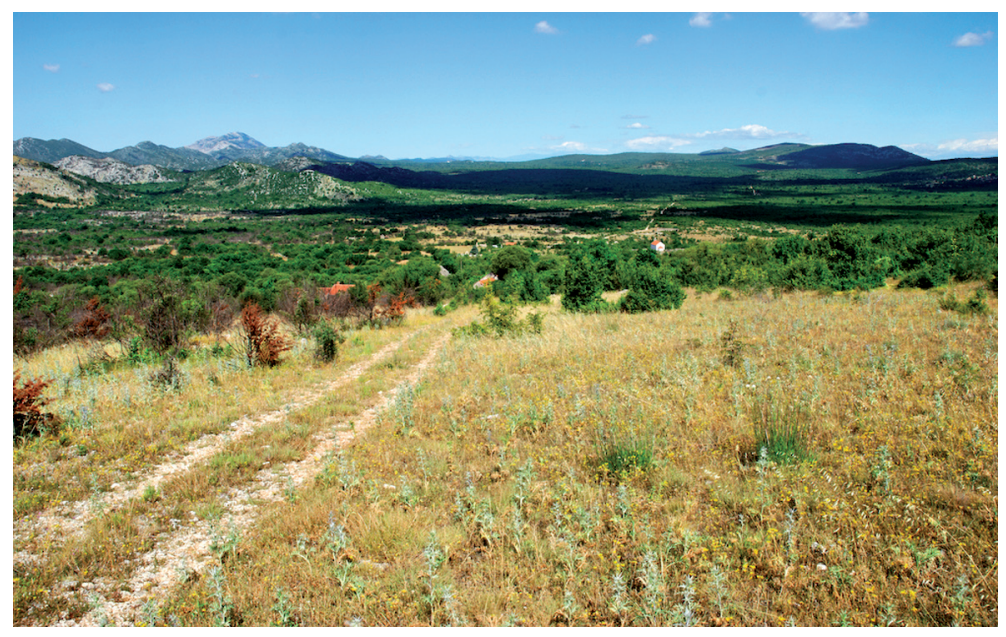

S1. 21. Crkva sv. Nikole u Gornjem Hrasnu i plato Hrasna

(foto: S. Vukorep)

Trasa rimske ceste ograđena je i sužena starim zidovima (ulica), širine 3,5 m. Uz Pelinov brijeg ide do izlaza na prijevoj (sedlo) kod Miloševića tora. Na samom kraju gdje trasa izlazi na prijevoj, granica je između općine Neum i Ravno. Također i na navedenoj dionici, uza samu trasu, nalaze se gomile, a nekoliko njih je u nizu. ${ }^{65}$

Desno od trase vidljivi su temelji nekog kružnog objekta, dok se s lijeve strane nalazi Miloševića torina, također, zanimljiv kružni objekt. $\mathrm{Na}$ zaravni prijevoja ispod Miloševića tora i čatrnje, u kraškom terenu dobro se uočava tlaka ceste ukopana u teren. Hodajući nekoliko stotina metara po visoravni, počinje se blago spuštati niza Zmijanje (pokraj prastare lokve) ${ }^{66}$ te prema selu Čavaš. ${ }^{67}$ Dužina ove dionice je $4,5 \mathrm{~km} .{ }^{68}$

$65 \mathrm{Na}$ izlazu Pelinov brijeg (prijevoj prema selu Čavaš) trasa prolazi između limitnih tumula - gomila koji su možda služili kao granica između općina Neum i Stolac (nekada u prapovijesti možda i granica između Plereja i Daorsa).

66 Kod mještana je sačuvana predaja da su lokvu gradili Grci koja nikada ne presušuje, te je bila važno pojilo uz ovu cestu. Trasu ceste od Miloševića tora do lokve obišli smo sa Slavkom Katićem i Davorom Bulićem, fotografom iz Neuma.

67 Trasa ceste od lokve do sela Čavaš minirana je u Domovinskome ratu pa ju je rizično obići (nalazi se na crti razgraničenja). Kako smo doznali od mještana put kroz polje od Čavša do "Velikog puta" nazivali su "Široki put", koji je polovicom šezdesetih godina 20. stoljeća uništen poljoprivrednim radovima. Prema kazivanju njime je "usporedo moglo ići 4 para volova u jarmu". Na navedeni put nastavlja se Veliki put kroz Lug i Šumu.

68 Topografska vojna karta 1:25000, Ston 2-2. U ovome radu korištene su i sekcije karata: Trebinje 1-4. Trebinje 1-3. 


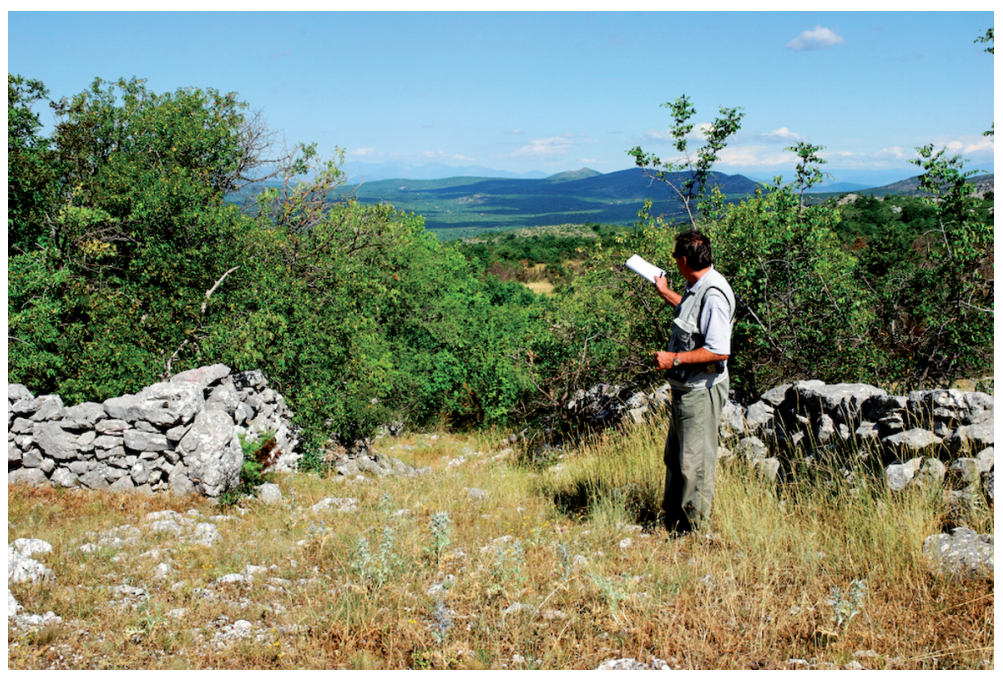

S1. 22. Izlaz iz Hrasna na Čavašku gradinu (foto: Ž. Pandža)

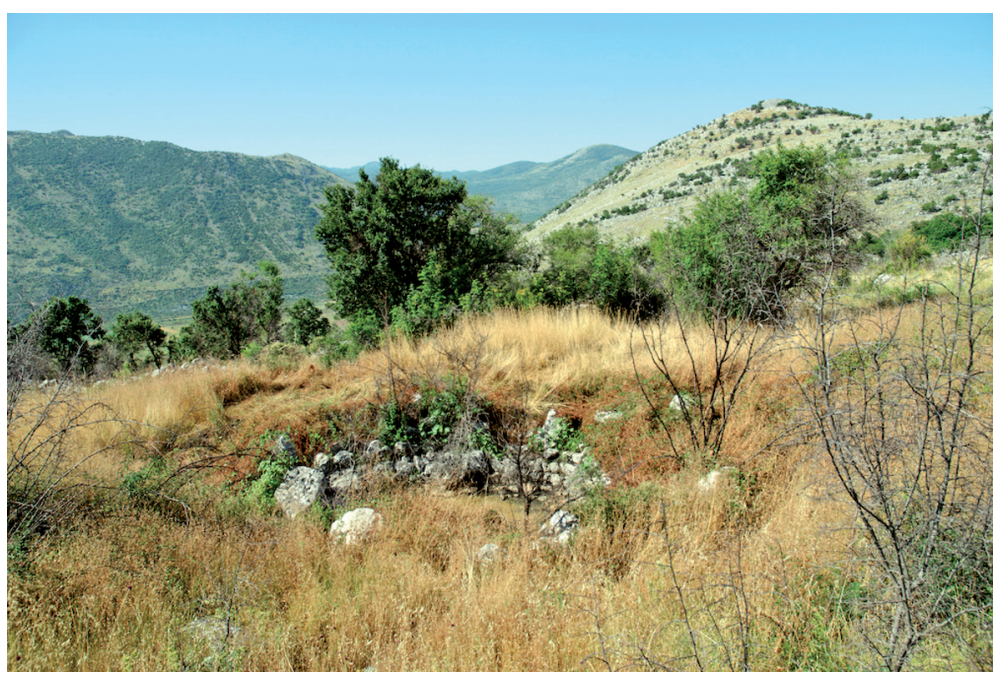

S1. 23. Lokva uz put pokraj Čavaške gradine (foto: S. Vukorep)

U proljeće, kada je vegetacija niska, promatrajući s željezničke pruge dionicu ceste od Zmijanja pa prema selu Čavašs, ${ }^{69}$ uočava se žuta crta koja označava samu cestu.

U selu Čavaš nalazi se čvorište putova, to jest s rimskoga puta odvajaju se konjski putovi za sela Bančiće, Mišljen i Ljubinje.

69 U selu Čavaš s rimskoga puta odvajaju se konjski putovi za sela Bančiće, Mišljen i dalje za Ljubinje. 


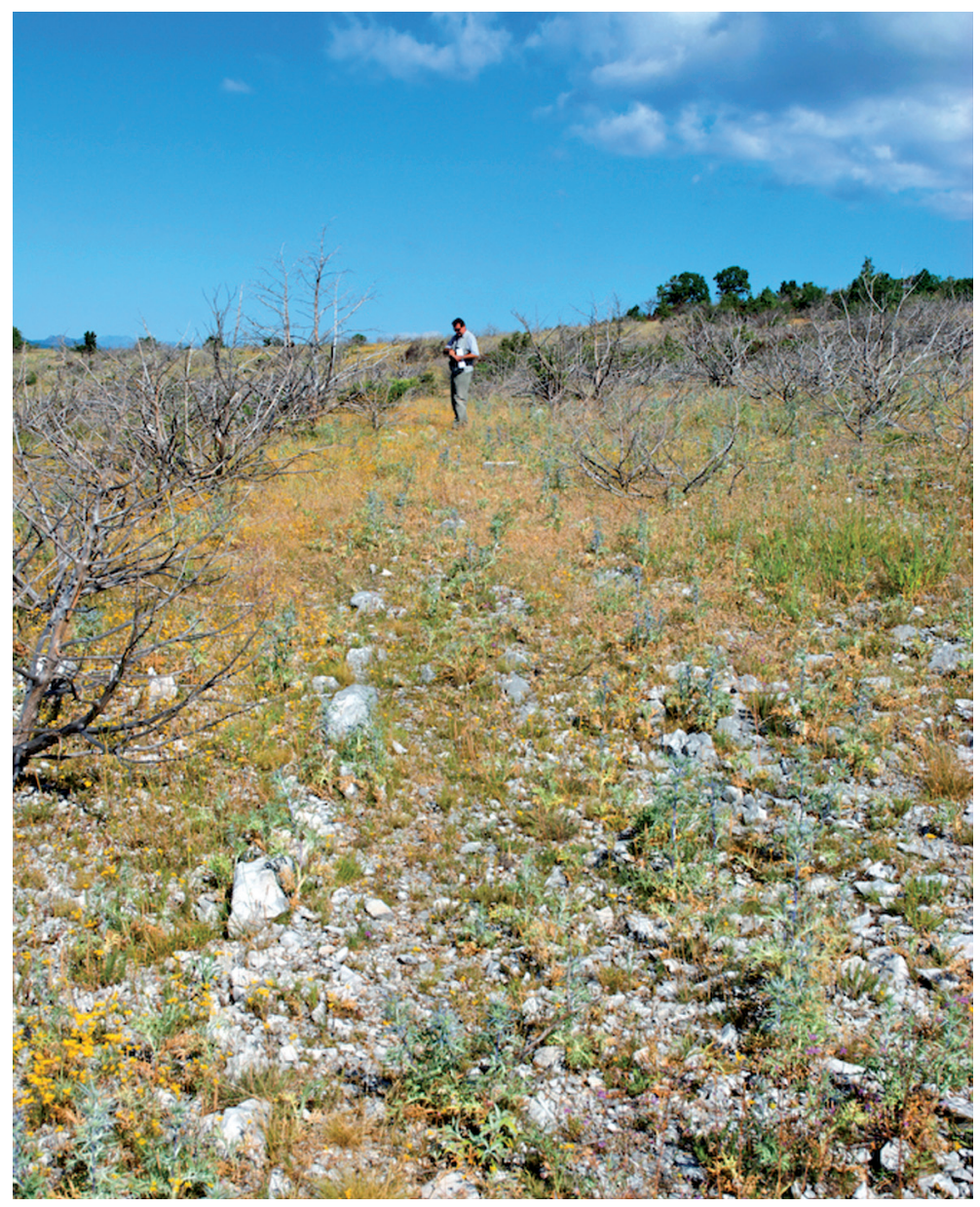

S1. 24. Detalj trase na Zmijanju (foto: Ž. Pandža)

\subsection{Dionica Čavaš - Most pod selom Sedlari ${ }^{70}$}

Selo Čavaš leži na rubu Popova polja gdje je silazna točka ovoga puta na Popovo polje. Polje koje je plavilo i na kome se voda zadnjih godina pred isušivanje zadržavala od sedam do devet mjeseci. Iznad polja je vodio konjski put za selo Orašje odakle je nastavljao pokraj groblja i nekropole stećaka. Jedan krak skretao je ulijevo prema Kotezima te dalje na istok.

70 Od Čavša rimska cesta ide teritorijem Republike Srpske. 


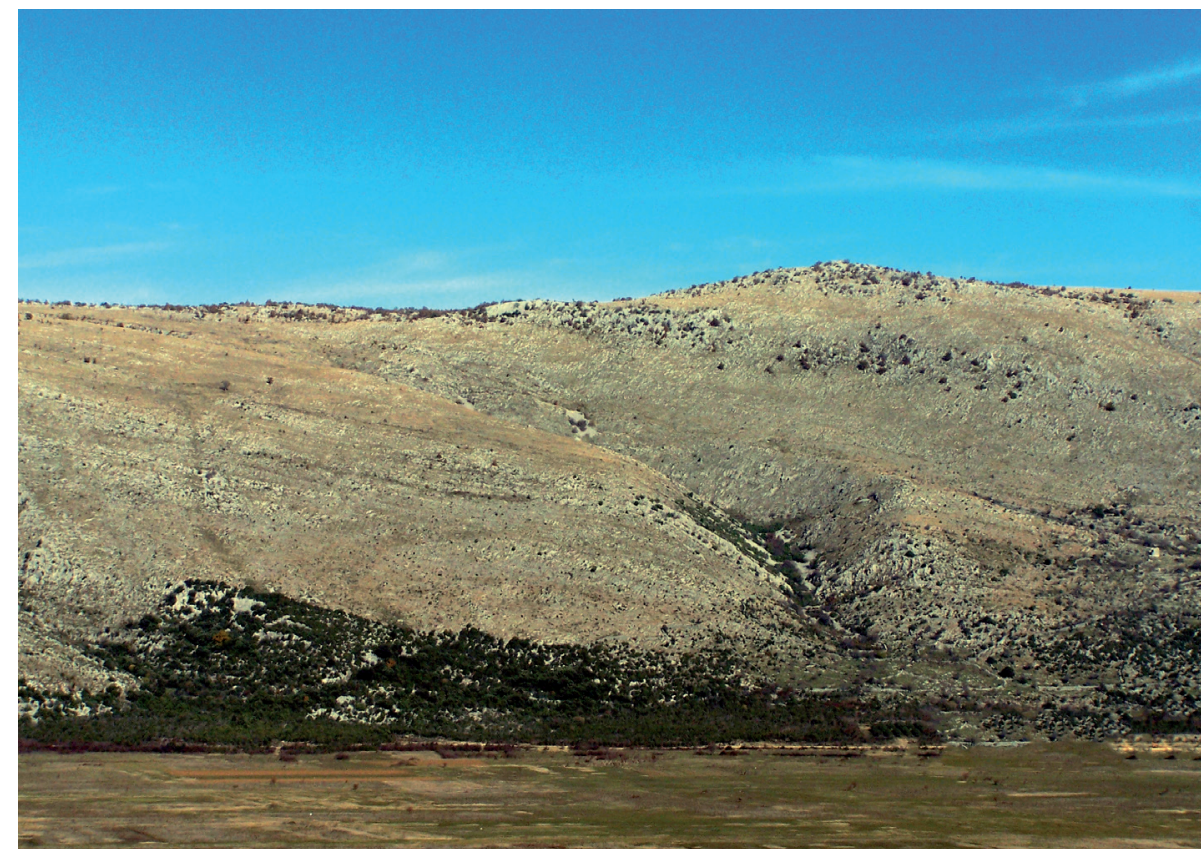

S1. 25. Silaz niz Zmijanje pred Čavašem (foto: Ž. Pandža)

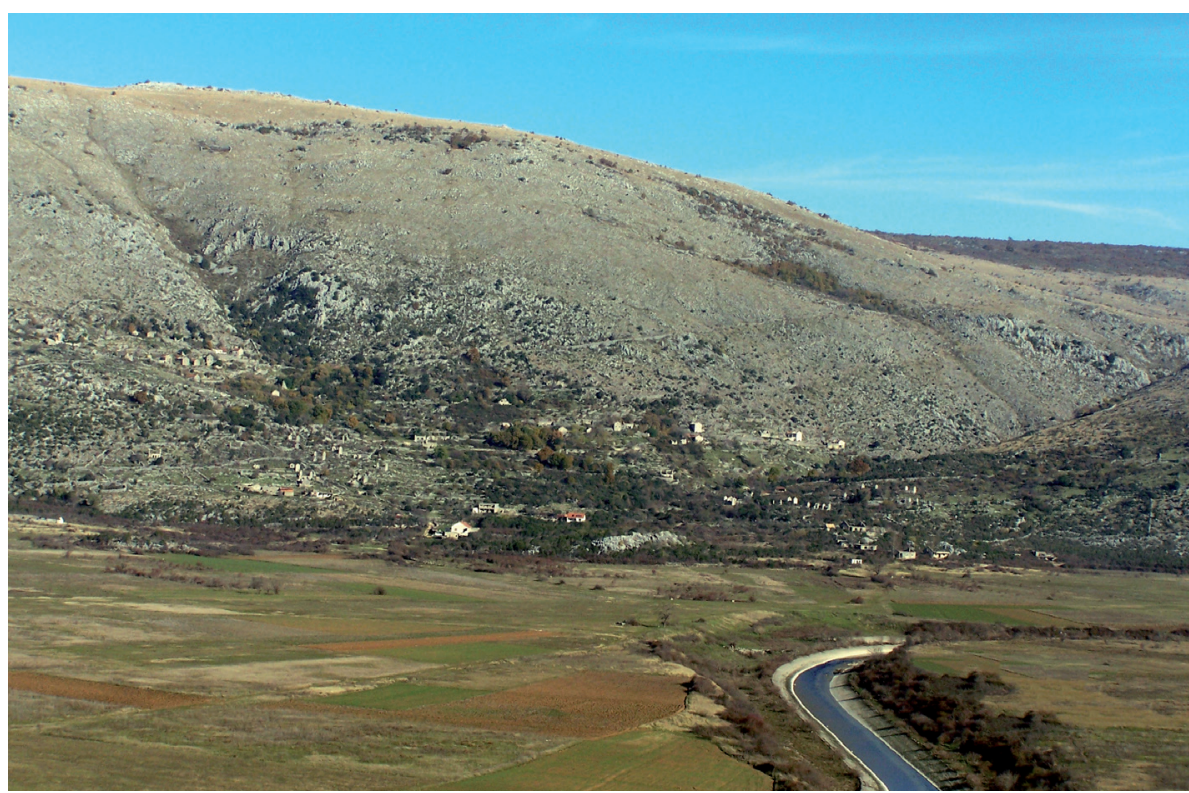

S1. 26. Selo Čavaš (foto: Ž. Pandža) 


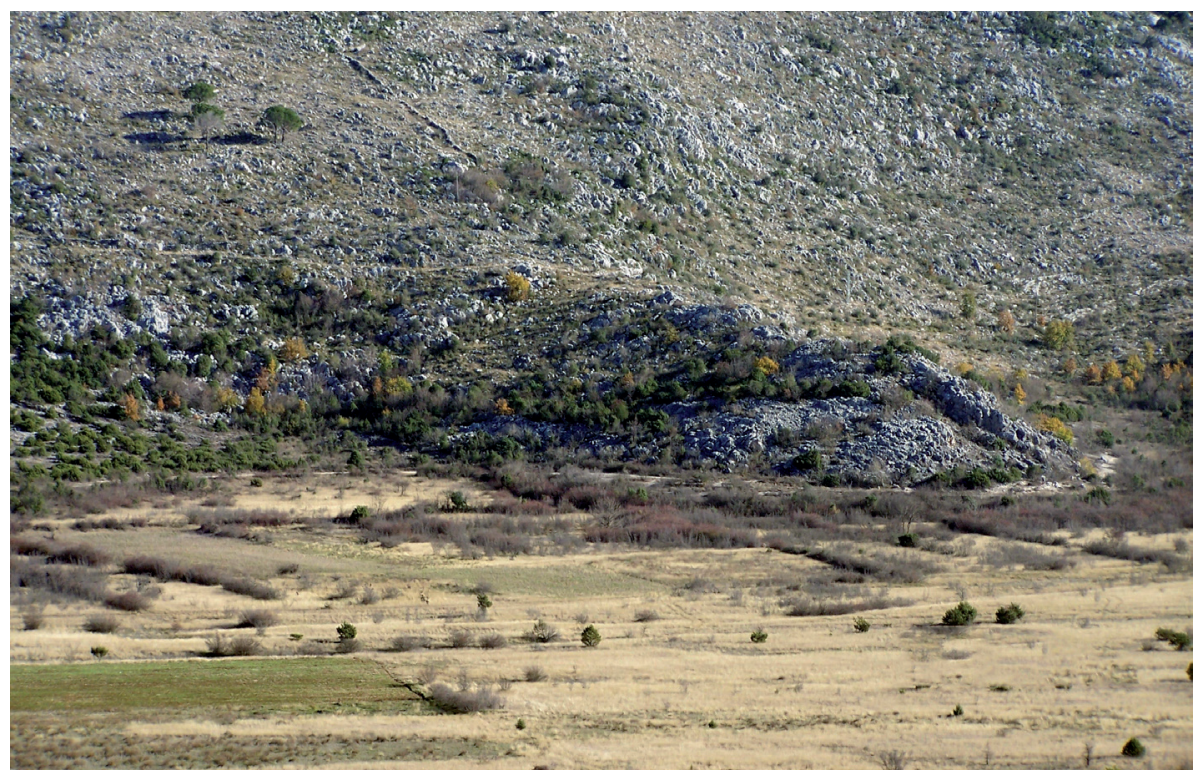

S1. 27. Orašje - stara cesta (foto: Ž. Pandža)

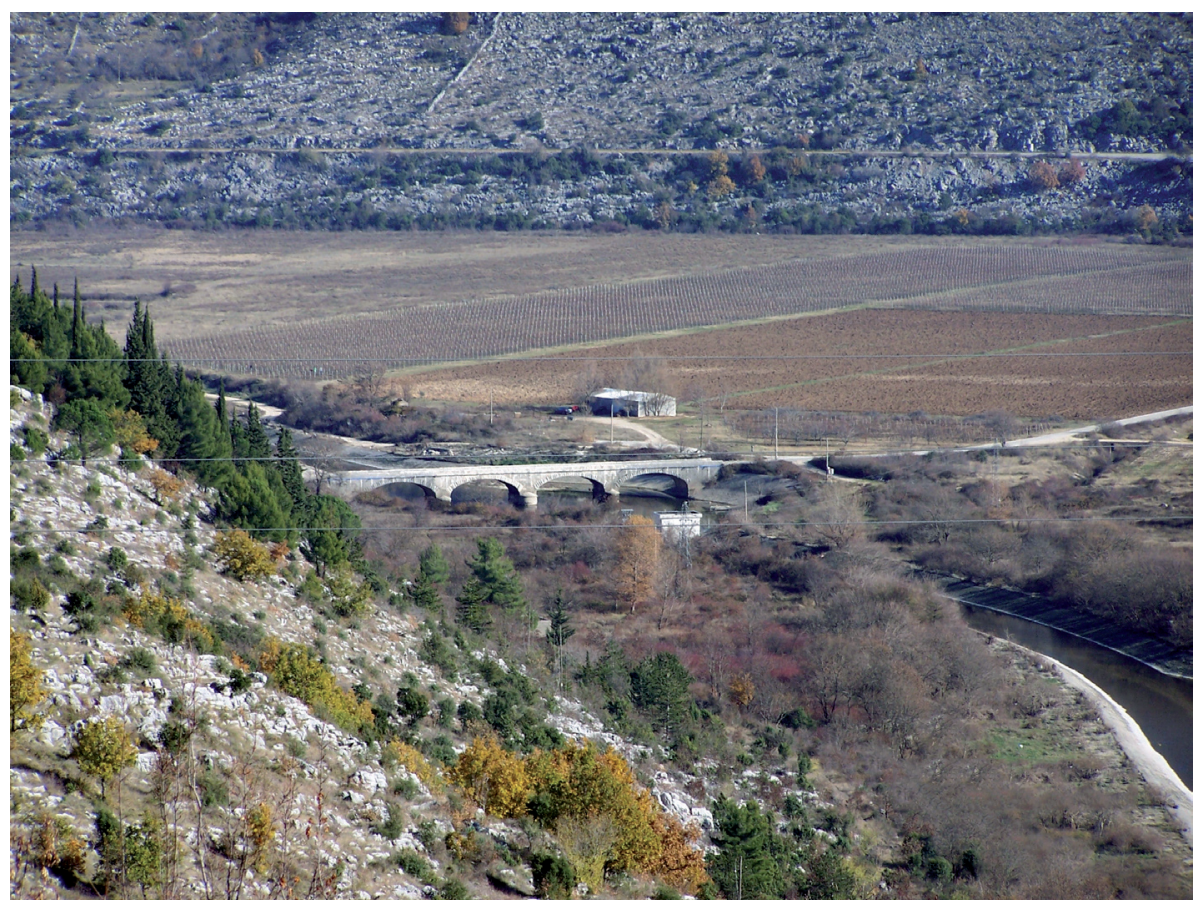

Sl. 28. Dvije trase starih cesta na izlazu iz Orašja - stara cesta preklopljena magistralnom prema Galičićima te cestom i mostom preko Trebišnjice pod Ravnim (foto: Ž. Pandža) 
U prapovijesno i antičko doba Popovo nije plavilo što potvrđuje tumul u Zablatku pod Okladnicom - Hutovo, ${ }^{71}$ koji je podignut na rubu polja na koti $245 .^{72}$ Isto potvrđuje i konjska čatrnja koja se nalazila na polju pod selom Čavašem, na koti 237,2 m. Budući da je režim voda na Popovu bio povoljan, to jest, polje od Čavša do Šume trebinjske nije plavilo (tonulo), rimska cesta zvana Široki put je pravom linijom išla poljem prema Lugu.

U Kotezima je K. Miller locirao Diluntum, ${ }^{73}$ iako na tom mjestu nije registrirano antičko naselje. Široki je put (ucrtan na svim starim kartama) poljem nastavljao selom Veličani gdje je otkriveno značajnije rimsko naselje ${ }^{74}$ te srednjovjekovna nekropola stećaka. U srednjem vijeku u Veličanima je bio lokalni centar desne strane Popova polja. ${ }^{75}$ Široki put iz Veličana nastavlja poljem ispod sela Dubljani, gdje se u blizini staroga srednjovjekovnog groblja i crkve sv. Đurđa nalazi lokalitet zanimljiva imena, Deseci, ${ }^{76}$ te toponim Toranj. Potom u ravnoj liniji ide poljem do ispod sela Sedlari, gdje se nalazio Voz (most, prijelaz) preko rijeke Trebišnjice. I ovaj dio ceste prate prapovijesne gradine koje se nalaze na visovima iznad polja sela Dubljani.

71 Dvadesetak kilometara južnije od Čavša.

72 Sigurno je da Iliri ne bi podizali grobnu humku u polju koje plavi.

73 Bojanovski municipij Diluntum smješta u Stolac. I. BoJAnovski, "Rimski natpisi iz doline Trebišnjice", str. 82-86; I. BojAnovski, Bosna i Hercegovina u antičko doba, str. 99.

74 Rimsko naselje (vjerojatno epihorskog karaktera) nalazilo se u blizini crkve, što potvrđuje arheološka građa. Ivo Bojanovski smatra da je u Radavama (lokalitet Konjuh) postojala klesarska radionica koja je radila u rimsko, a poslije i u srednjovjekovno doba, jer je na tom lokalitetu pronašao dosta obrađenog klesanog kamena. Pod cestom ispod crkve u Veličanima pronađeni su zidovi u krečnom malteru, dijelovi dovratnika, keramika i dr. I. BoJANovski, "Rimski natpisi iz doline Trebišnjice", str. 77-78.

75 Iz Popova polja potječe šest rimskih novčića koji se nalaze u Zemaljskom muzeju u Sarajevu.

76 Imamo sličan toponim Dicmo (između Dugopolja i Sinja). Po mišljenju Petra Skoka ovaj toponim potječe od latinskoga rednog broja decimus (deseti) i vjerojatno je ostatak duljeg naziva Ad decimum lapidem, to jest, kod desetog miljokaza na rimskoj cesti od Splita prema Andetriumu (Gornjem Muću). O navedenoj cesti pogledati, I. BoJanovski, Dolabelin sistem cesta..., str. 51-55, 130-132; Petar Sкок, Etimologijski rječnik hrvatskoga ili srpskoga jezika, Zagreb, 1971., str. 400. 
ŽELJKA PANDŽA - STANISLAV VUKOREP - RIMSKA CESTA OD VIDA....

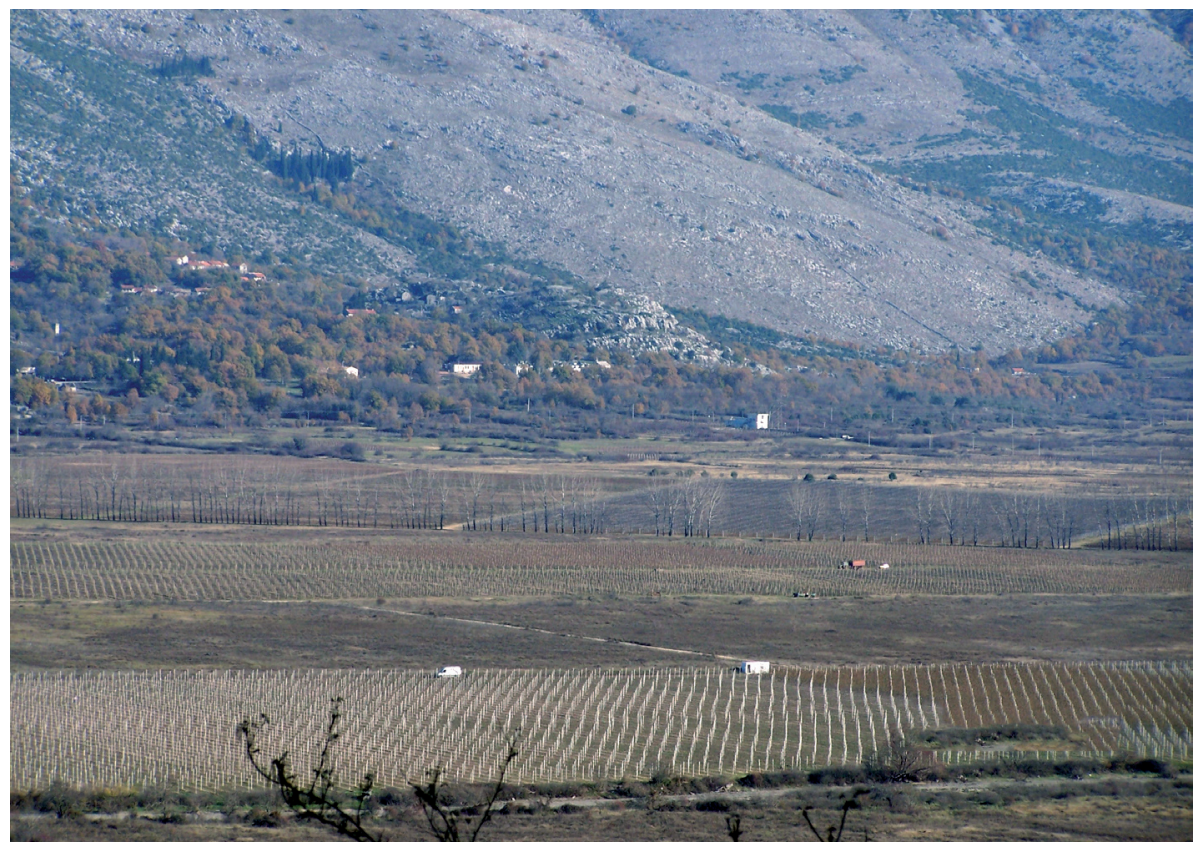

S1. 29. Popovo polje - Selo Veličani (foto: Ž. Pandža)

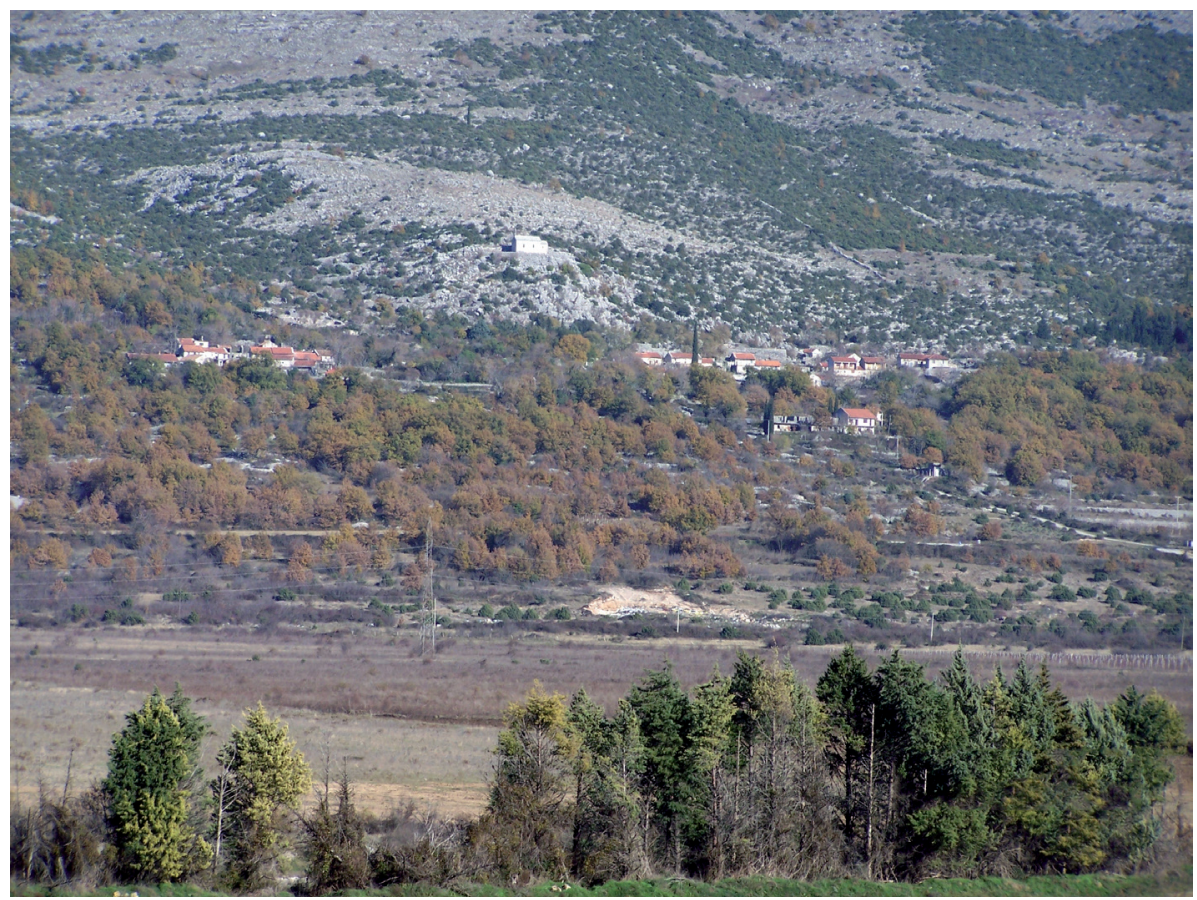

S1. 30. Selo Dubljani (foto: Ž. Pandža) 


\subsection{Dionica Most pod Sedlarima - Cicina kod Huma}

Od Voza ${ }^{77}$ (sada most) pod selom Sedlari do Cicine trasa rimske ceste je duga oko $14 \mathrm{~km}$. Od Voza ide ispod sela Poljice, odakle počinje područje Luga (kraško područje). Ispod sela Poljica trasu ceste je vjerojatno manjim dijelom preklopila trasa željezničke pruge, pa od kot. 254. nastavlja dalje kao Veliki put (Karavanski put) u ravnoj liniji do Huma.

U blizini Poljica nalazi se lokalitet Međine na kojem se nalaze dva brežuljka i uokolo njih 8 do 10 gomila, a sve je omeđeno zidinama. ${ }^{78}$ Potom cesta prolazi ispod gradine Kličanj, kroz Debeli lug pokraj sela Krnjevića te vodi prema brdu Hum, kojeg obilazi s istočne strane, te nastavlja dalje prema selu Cicini.

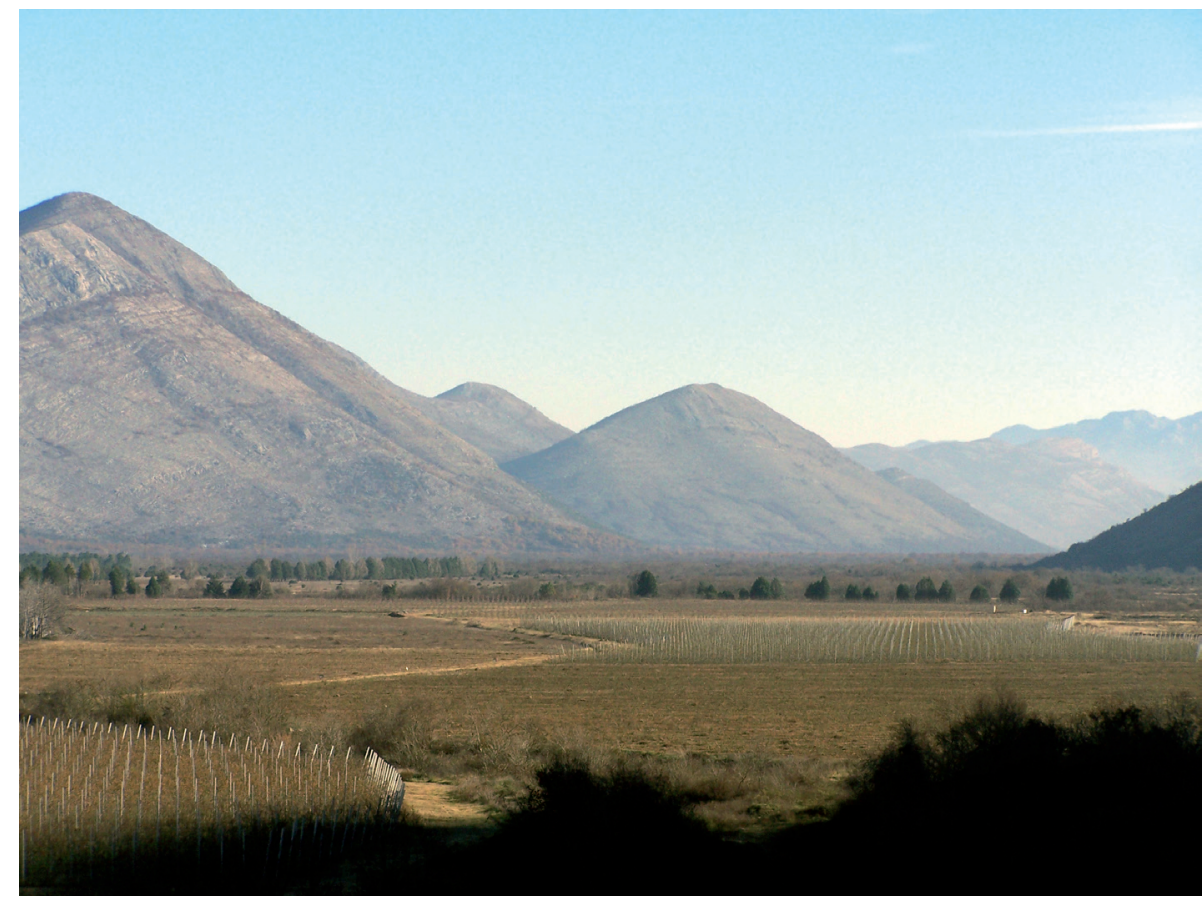

S1. 31. Kraj Popova polja i početak Luga (foto: Ž. Pandža)

77 Voz ili Most. Po narodnom kazivanju Voz je zapravo prijelaz preko rijeke.

78 Navedeni lokalitet je udaljen oko 500 metara od Velikoga puta (Karavanskoga puta). 


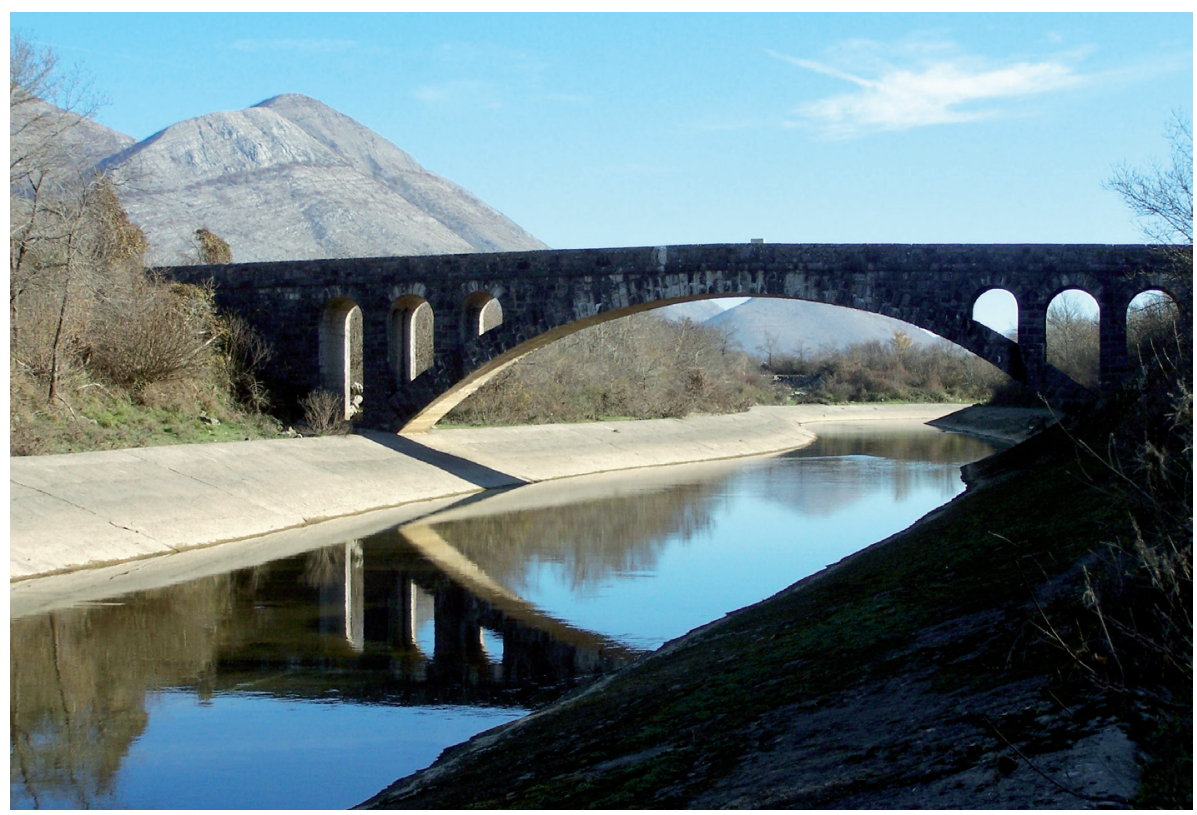

S1. 32. Novi most preko Trebišnjice pod Sedlarima (foto: Ž. Pandža)

Trasu rimske ceste od Doljana do Huma nije nitko od arheologa do sada detaljno istražio tako je i pitanje miljokaza upitno do Veličana u Popovu. Do sada pronađeni miljokazi su na Velikom putu u blizini Huma. ${ }^{79}$ Pokraj puta u selu Nenovićima nalazi se rimski miljokaz na kome je u reljefu isklesan križ. U selu Đedićima također se nalazi izvrnuti rimski miljokaz oblim dijelom zaboden u zemlju. Površinska likovna analiza pokazuje tri faze: miljokaz, isklesavanje križeva, i postavljanje u obrnut položaj te urezivanje natpisa ${ }^{80}$ Treći miljokaz pronađen je u blizini Zborne gomile, uza stari kaldrmirani (napušten) put ${ }^{81}$ ispod sela Lug.

79 Jedno od manjih rimskih naselja a koje je dokazano arheološkim ostatcima: temelji zgrada, građevinski materijal, grobovi, epigrafski spomenici, rimski novac i dr., ležalo je pod gradinom Hum (po narodnoj predaji nazivalo se "grčko" naselje a razvilo se na autohtonoj osnovi) koja dominira cijelom Trebinjskom šumom, na njivama tzv. Višnjice i Rosulje pokraj starog puta koji je ravnicom (južnom periferijom naselja) u ravnoj liniji vodio prema Poljicama. Na iskrčenim parcelama nailazilo se na lomljeni kamen s malterom, ulomci opeka i crijepa, troska i dr. $\mathrm{Na}$ parceli Mirka Mičovića Kolaka nađeni su temelji zgrade. I. BoJAnovski, "Rimski natpisi iz doline Trebišnjice", str. 67-68.

80 Pavao AnĐelić, "Srednjovjekovna župa Popovo", u: Tribunia, 7, Trebinje, 1983., str. 61-79.

81 Isto, str. 71. 


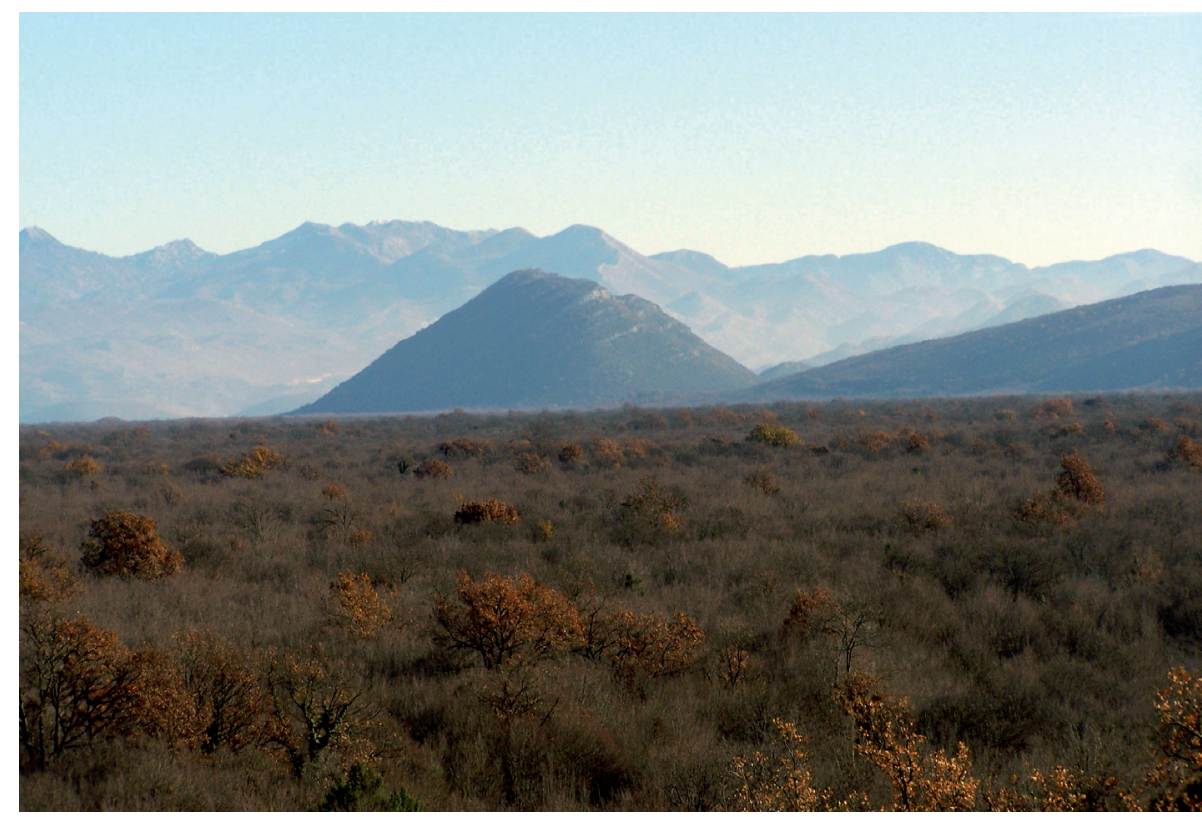

S1. 33. Lug - u pozadini brdo i gradina Hum (foto: Ž. Pandža)

Pretpostavljamo da je kasnije (2. ili 3. st.) na području gdje su pronađeni miljokazi bilo veće križanje putova pa su postavljeni da usmjeravaju putnike. I ovaj putni pravac karakterističan je za rimske ceste, a izlazio je u Bjelin dolu ${ }^{82}$ gdje je bila željeznička stanica Hum. Na širem području Huma registrirane su prapovijesne gradine i antička naselja.

\section{Cicina - Trebinje}

Od sela Cicine cesta nastavlja dalje prema Trebinju u dužini od oko 11 $\mathrm{km}$. Vodi u ravnoj crti do sela Petrovića (na karti konjski put) te dalje do Donjih Miovića (na karti kao staza) gdje skreće ulijevo te kod Dražin dola prelazi rijeku Trebišnjicu.

Poklopljena je suvremenom komunikacijom, skreće za Zasad i Mostaće i ulazi na plato Trebinja. U Trebinju se odvaja jedan pravac preko Aleksine Međe i Čičeva ${ }^{83}$ te dalje vodi za Epidaur. (Od Trebinja do Epidaura trasa rimske ceste ustanovljena je na terenu.)

82 Križanje putova u srednjem vijeku bilo je na spomenutom Bjelin dolu.

83 Skupina Autora, Arheološki leksikon Bosne i Hercegovine, sv. III., str. 171. Selo Čičevo nalazi se južno od Trebinja, ali na trebinjskom području. U Čičevu (pokatkad se naziva Crnač ili Dživar) nalazilo se rimsko naselje (na njivama Lijeske nađeni su ostatci antičke građevine), srednjovjekovna crkva i benediktinski samostan. 
Spomenuli bi i cestu od Cicine preko Huma i Taleže ${ }^{84}$ na Duži. S Duži je nastavljala na Dražin dol gdje je prelazila rijeku Trebišnjicu i ulazila u Trebinje. Cijela trasa rimske ceste od Doljana do Cicine - Hum na terenu i karti izgleda kao blago savijena crta, ali s dosta dugih pravaca znalački odabranim i jedino mogućim. Mišljenja smo da je opisana rimska cesta od Vida do Cicine išla dalje smjerom koji smo naveli pod Cicina - Trebinje, gdje se spajala s već utvrđenom rimskom cestom.

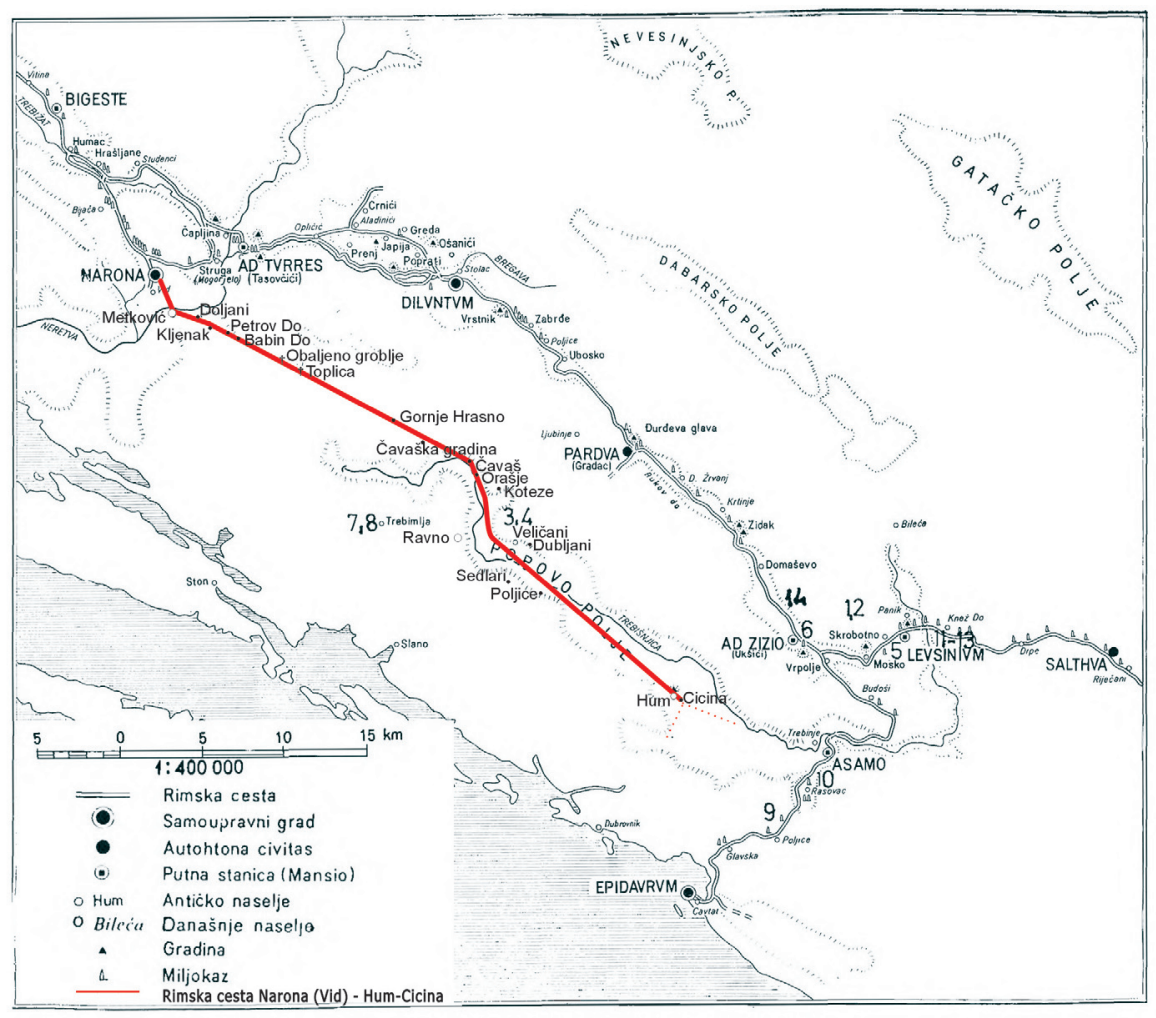

S1. 34. Rimska cesta Vid - Cicina kod Huma (fecerunt: Ž. Pandža i S. Vukorep)

84 Enver Imamović, Antički kultni i votivni spomenici na području BiH, Sarajevo, 1977., str. 404. U Taleži kod Trebinja pronađena je mala brončana statueta rimske božice lova, Dijane. 


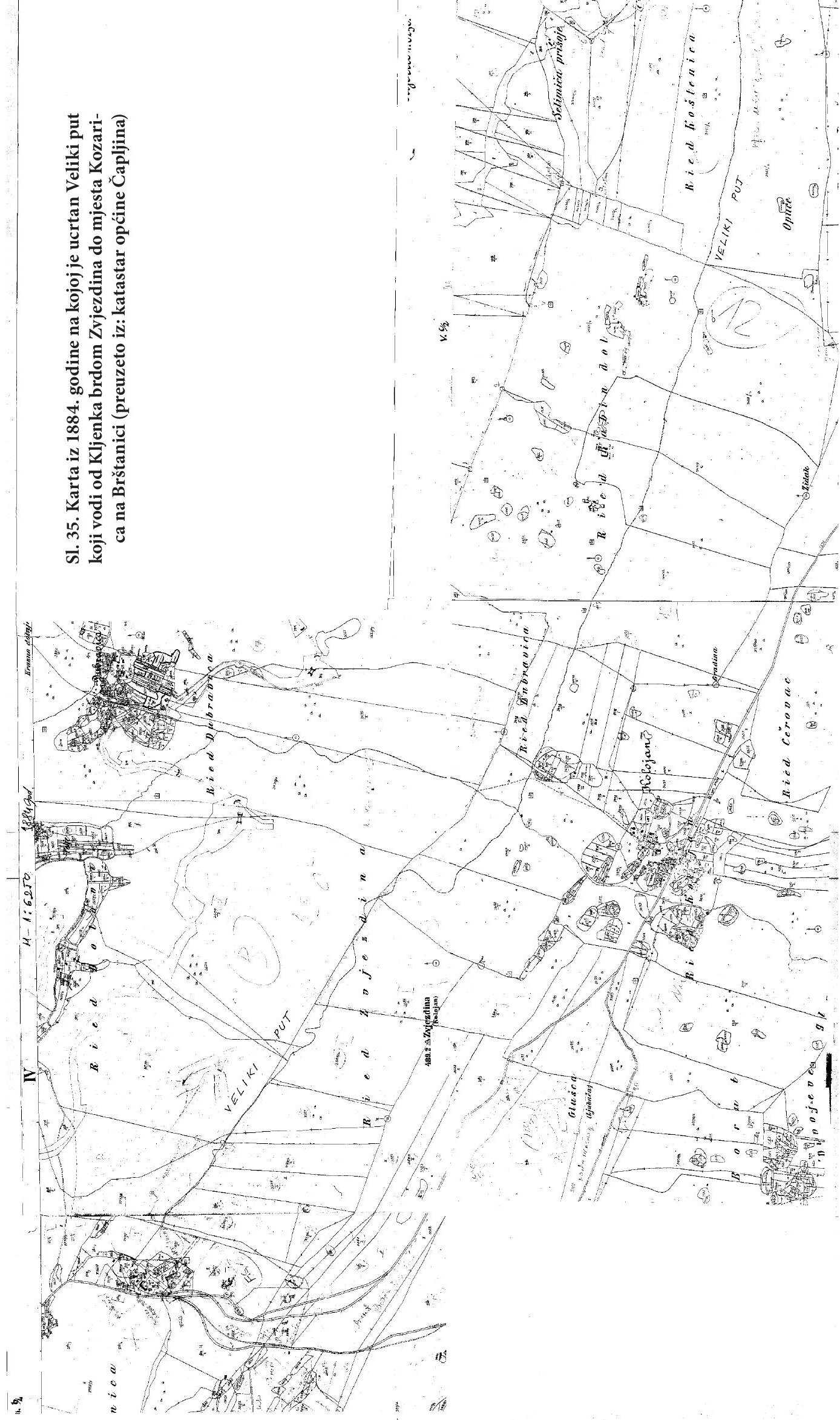




\section{Zaključak}

U ovomu radu pokušali smo dokazati postojanje dosad neistražene rimske ceste koju smo trasirali od Vida (Narona) do Cicine u blizini Trebinja. Sam opis ceste i njezino prepoznavanje radili smo pomoću hodoloških pretraživanja na terenu i analizom topografskih karata. Smatramo da imamo nekoliko tehnoloških pokazatelja koji nam potvrđuju da je navedena cesta doista bila rimska, a to su ivičnjaci, nalazi novca i ostava, širina koja je naizmjenično od 2 do $4,5 \mathrm{~m}$, trasiranje dugih potpuno ravnih dionica, način postupnoga svladavanja uspona, uklopljenost $\mathrm{u}$ ostatak mreže rimskih cesta, ostatci naselja, nekropole s nadgrobnim spomenicima i natpisima, kao i kazivanje stanovništva ovoga područja koje je neke od dionica nazivalo Veliki put, Stari put, Široki put ili Karavanski put.

Sve navedeno potvrđuje da je cesta opisana u ovomu radu doista rimska, to jest, cesta koja je izgrađena u vrijeme kada su Rimljani vladali ovim područjem, iako je prije njihova dolaska ovim pravcem već postojao put kojeg je koristilo domorodačko pučanstvo. Budući da nedostaju nalazi miljokaza, nemamo potvrdu u kojem je razdoblju izgrađena ova komunikacija, možemo zato samo pretpostaviti da njezina gradnja pripada vremenu nakon što su sagrađeni osnovni magistralni pravci u provinciji Dalmaciji, a to je vrijeme od 1 . do 3. st. Na kraju, smatramo važnim spomenuti mogućnost da je navedena rimska cesta možda jedna kraća varijanta magistralne trase Narona - Epidaur, a koja ide preko Narone, Stoca i Trebinja, (gdje se spajaju) te dalje nastavlja za Epidaur. Stanovnici antičke Narone u tom slučaju nisu imali potrebe ići dužim zaobilaznim putom koji je vodio preko Stoca i Trebinja u Epidaur, nego su to činili idući putom koje je autohtonom stanovništvu bio poznat i prije, a kojeg su Rimljani svojim dolaskom na ovo područje unaprijedili te izgradili cestu kojom će se moći "mimoići dvoja kola" te tako na lakši i brži način doći do odredišta.

Rimska cesta o kojoj smo u ovomu radu govorili išla bi ovim pravcem:

Vid - Doljani - Kljenak - brdo Zvjezdina - Hrasno - Čavaška gradina Čavaš - Lug - Trebinjska šuma - Hum - Cicina, te dalje do Trebinja.

Rimske ceste u provinciji Dalmaciji, osobito u unutrašnjosti, nisu dovoljno istražene. Stoga se nadamo da će ovaj rad i utvrđena rimska cesta potaknuti znanstvenike da se u budućnosti više posvete istraživanju antičkih komunikacija ovoga područja. 


\section{Roman road from Vid (Narona) in the Neretva river valley to the village of Cicina - Hum near Trebinje}

\section{Summary}

The paper describes a hitherto unexplored Roman road leading from Narona (today Vid near Metkovic) to the village of Hum - Cicina near Trebinje with a total length of about 68 kilometers. It further continued to Trebinje, where it joined the itinerary road from Narona to Epidaurus, which was discovered in the eighties of the twentieth century. We believe that the mentioned road was built (on the existing prehistoric road) at the time of Roman rule in this area, probably in the period after the basic main roads in the province of Dalmatia were constructed, i.e. from the 1st to the 3rd century. After hodological and topographic explorations of a part of the route and a narrow area along the route, we assume that this was primarily a military Roman road (at first of strategic and later economic importance), which was its primary function. The fact that it was used as a military facility can be supported by its relatively straightforward course. That the road was really Roman can be confirmed by several technical indicators (curbs, coins and storage findings, its width from 2 to $4.5 \mathrm{~m}$, remains of settlements, tracing of long completely straight sections etc.), as well as by the indigenous population referring to some of the road sections even today as Great road, Old road, Wide road and the like.

Keywords: Illyrian, Roman Province of Dalmatia, Romans, the Neretva river valley, road construction, location of Roman road, Narona, Doljani, Cavac in Popovo polje, Hum, road sections, Epidaurus. 